\title{
Inter-annual variability of precipitation constrains the production response of boreal Pinus sylvestris to nitrogen fertilization
}

\author{
Hyungwoo Lim ${ }^{\mathrm{a}}$, Ram Oren ${ }^{\mathrm{ab} *}$, Sari Palmroth ${ }^{\mathrm{ab}}$, Pantana Tor-ngern ${ }^{\mathrm{b}}$, Tommy Mörling ${ }^{\mathrm{a}}$, \\ Torgny Näsholm ${ }^{\mathrm{a}}$, Tomas Lundmark ${ }^{\mathrm{a}}$, Heljä-Sisko Helmisaari ${ }^{\mathrm{c}}$, Jaana Leppälammi- \\ Kujansuu $^{\mathrm{c}}$, and Sune Linder ${ }^{\mathrm{d}}$
}

${ }^{\mathrm{a}}$ Department of Forest Ecology and Management, Swedish University of Agricultural Sciences, (SLU), SE-901 83, Umeå, Sweden

${ }^{\mathrm{b}}$ Division of Environmental Science \& Policy, Nicholas School of the Environment, Duke University, Durham, NC 27708, U.S.A.

${ }^{\mathrm{c}}$ Department of Forest Sciences, University of Helsinki, P.O. Box 27, FI-00014, Helsinki, Finland

${ }^{\mathrm{d}}$ Southern Swedish Forest Research Centre, SLU, P.O. Box 49, SE-230 53, Alnarp, Sweden

Key words: Carbon partitioning, Climate variation, Leaf area index, Light interception, Net primary production, Scots pine, Temperature

*Corresponding author, Tel.: +1 919 6138032; Fax: +1 919 6848741; e-mail:

ramoren@duke.edu

E-mail addresses: hyungwoo.lim@slu.se (H. Lim), ramoren@duke.edu (R. Oren),

sari.palmroth@duke.edu (S.Palmroth), yespoy@gmail.com (P. Tor-ngern), tommy.morling@slu.se (T. Mörling), torgny.nasholm@ @lu.se (T. Näsholm), tomas.lundmark@ slu.se (T. Lundmark), heljasisko.helmisaari@helsinki.fi (H.-S. Helmisaari), jaana.leppalammi-kujansuu@helsinki.fi (J. Leppälammi-Kujansuu), sune.linder@slu.se (S. Linder). 


\section{H. Lim et al.}

\section{Abstract}

Tree growth resources and the efficiency of resource-use for biomass production determine the productivity of forest ecosystems. In nutrient-limited forests, nitrogen (N)-fertilization increases foliage $[\mathrm{N}]$, which may increase photosynthetic rates, leaf area index $(L)$, and thus light interception $\left(I_{\mathrm{C}}\right)$. The product of such changes is a higher gross primary production and higher net primary production (NPP). However, fertilization may also alter carbohydrate partitioning from below- to aboveground, increasing aboveground NPP (ANPP). We analyzed effects of long-term N-fertilization on NPP, and that of long-term carbon storing organs $\left(\mathrm{NPP}_{\mathrm{S}}\right)$ in a Pinus sylvestris forest on sandy soil, a wide-ranging forest type in the boreal region. We based our analyses on a combination of destructive harvesting, consecutive mensuration, and optical measurements of canopy openness. After eight-year fertilization with a total of $70 \mathrm{~g} \mathrm{~N} \mathrm{~m}^{-2}$, ANPP was $27 \pm 7 \%$ higher in the fertilized (F) relative to the reference (R) stand, but although $L$ increased relative to its pre-fertilization values, $I_{\mathrm{C}}$ was not greater than in R. On the seventh year after the treatment initiation, the increase of ANPP was matched by the decrease of belowground NPP (78 vs. $92 \mathrm{~g} \mathrm{C} \mathrm{m}^{-2} \mathrm{yr}^{-1} ; \sim 17 \%$ of NPP) and, given the similarity of $I_{\mathrm{C}}$, suggests that the main effect of $\mathrm{N}$-fertilization was changed carbon partitioning rather than increased canopy photosynthesis. Annual NPP increased linearly with growing season temperature $(T)$ in both treatments, with an upward shift of $70.2 \mathrm{~g} \mathrm{C} \mathrm{m}^{-2}$ $\mathrm{yr}^{-1}$ by fertilization, which also caused greater amount of unexplained variation $\left(r^{2}=0.53\right.$ in $\mathrm{R}, 0.21$ in F). Residuals of the $\mathrm{NPP}_{\mathrm{S}}-T$ relationship of $\mathrm{F}$ were related to growing season precipitation $\left(P, r^{2}=0.48\right)$, indicating that $T$ constrains productivity at this site regardless of fertility, while $P$ is important in determining productivity where $\mathrm{N}$-limitation is alleviated. We estimated that, in a growing season average $T\left(11.5 \pm 1.0{ }^{\circ} \mathrm{C} ; 33\right.$-year-mean $), \mathrm{NPP}_{\mathrm{S}}$ response to N-fertilization will be nullified with $P 31 \mathrm{~mm}$ less than the mean $(325 \pm 85 \mathrm{~mm})$, and would double with $P 109 \mathrm{~mm}$ greater than the mean. These results suggest that inter-annual 


\section{H. Lim et al.}

variation in climate, particularly in $P$, may help explaining the reported large variability in growth responses to fertilization of pine stands on sandy soils. Furthermore, forest management of long-rotation systems, such as those of boreal and northern temperate forests, must consider the efficiency of fertilization in terms of wood production in the context of changes in climate predicted for the region.

\section{Introduction}

The production of biomass in forest ecosystems at a particular regime of incoming solar radiation is the outcome of the amount of radiation absorbed by the canopy and its utilization in the production of carbohydrates and further of biomass. The amount of photosynthetically active radiation intercepted by the canopy $\left(I_{\mathrm{C}}\right)$ depends on both the canopy leaf area index $(L)$ and its spatial organization (Stenberg, 1996; Nilson, 1999; Stenberg et al., 2001; Kim et al., 2011). Converting $I_{C}$ to biomass depends on processes sensitive to temperature, soil moisture and nutrient availability (Monteith, 1977; Linder, 1987; Runyon et al., 1994; Haxeltine and Prentice, 1996).

In the nutrient-limited boreal forests, many studies on conifers have shown that nitrogen (N)-fertilization enhances productivity and resource-use efficiency (e.g. Kukkola and Saramäki, 1983; Axelsson and Axelsson, 1986; Mälkönen et al., 1990; Mälkönen and Kukkola, 1991; Tamm, 1991; Valinger, 1993; Bergh et al., 2005; Jacobson and Pettersson, 2010). Depending on initial conditions, reducing or eliminating N-limitation through $\mathrm{N}$ fertilization could increase aboveground biomass production in three ways: (1) by increasing $L$ and thus $I_{\mathrm{C}},(2)$ by increasing photosynthetic rates of foliage (per unit area), both of which contribute to increases of gross primary production (GPP, or whole canopy photosynthesis), and (3) by shifting carbohydrate partitioning from belowground production of fine-roots and mycorrhizae to favor aboveground production of foliage and wood (Linder and Axelsson, 


\section{H. Lim et al.}

1982; Vose and Allen, 1988; Colbert et al., 1990; Cromer and Jarvis, 1990; Haynes and

Gower, 1995; Albaugh et al., 1998; Nilsson and Wallander, 2003).

Inter-annual and geographical variation of temperature and precipitation exert large influence on NPP (Melillo et al., 1998; Knapp and Smith, 2001) by affecting GPP and carbohydrate partitioning to belowground (Litton and Giardina, 2008). At a macro scale, spatial variation in temperature is known to affect site productivity (Fries et al., 1998), but even small topographic gradients at a decameter scale introduce spatial variability of moisture and soil water holding capacity, which can influence local productivity (Sampson and Allen, 1999; McCarthy et al., 2007; Noormets et al., 2010). However, the effect of inter-annual variation of weather conditions on NPP response to fertilization was seldom assessed (Oren et al., 2001; Nilsen and Abrahamsen, 2003; Jacobson and Pettersson, 2010), especially over periods sufficiently long to allow functional responses to emerge (Samuelson et al., 2014). Such responses are essential for performing cost-benefit analysis on fertilization, as the benefit is entirely dependent on the response to fertilization (Jacobson and Pettersson, 2010). If the response to fertilizing depends on inter-annual variation in weather, the mean and extremes of which may change with global climate, forest managers may need to employ functional responses together with climate prediction to obtain estimates of future responses, especially in long-rotation systems. Indeed, recent work on adaptive forest management suggests periodic reassessment of silvicultural treatments in the context of environmental and climatic changes (Spittlehouse and Stewart, 2003; Seppälä et al., 2009; Lindner et al., 2010; Janowiak et al., 2014).

Among the diverse goals of forest management, the primary goal of fertilization is to increase the production of wood fiber. Another can be to increase carbon (C) sequestration in long-lasting woody biomass (stem wood, branches, coarse-roots, and cones). Belowground C flux in forest ecosystem often accounts for a considerable fraction of GPP (Ryan, 1991), and 


\section{H. Lim et al.}

may even exceed NPP (Law et al., 1999). In Pinus sylvestris forests, NPP belowground (BNPP) may range widely, between one and two-thirds of NPP (Linder and Axelsson, 1982; Helmisaari et al., 2002; Xiao et al., 2003) decreasing with soil nutrient availability. Yet, generally N-fertilization studies show inconsistent effects on total belowground C flux, ranging from no change in over three-year long experiment in tropical Eucalyptus saligna plantations (Giardina et al., 2003), to a decrease in temperate pine stands (Haynes and Gower, 1995; Palmroth et al., 2006). The majority of studies from boreal and temperate forests showed that $\mathrm{N}$-fertilization reduces soil respiration and/or microbial biomass, indicating a reduction of C flux to belowground (Franklin et al., 2003; Lee and Jose, 2003; Olsson et al., 2005; Oishi et al., 2014).

The objectives of this study were to examine the effect of $\mathrm{N}$-fertilization on biomass production of a boreal mature $P$. sylvestris stand and its interaction with inter-annual variation of climate conditions using a combination of destructive harvesting, consecutive standard mensuration measurements, and optical measurements of canopy openness over eight years. The study was conducted in the footprints of eddy-covariance flux measurement towers, meaning control and fertilized plots were not randomly located, representing pseudoreplication. Thus, although the site in which the two towers are located is very uniform, we included stand characteristics as co-variables to account for differences in preexisting conditions, the major concern with pseudo-replicated studies. Our hypotheses were that Nfertilization enhances production by (H1) enhancing light capture (Giardina et al., 2003; Bergh et al., 2005) and (H2) enhancing $\mathrm{C}$ investment aboveground at the expense of belowground partitioning (Linder and Axelsson, 1982; Ingestad and Ågren, 1991; Haynes and Gower, 1995; Ericsson et al, 1996; Palmroth et al., 2006). We also expected that (H3) the inter-annual variability of (a) temperature and (b) precipitation interacts with fertilization 
H. Lim et al.

resulting in variable NPP responses (Linder, 1987; Linder et al., 1987; Tamm et al., 1999;

Bergh et al. 2005; Choi et al., 2005). 


\section{Materials and methods}

\subsection{Setting}

The study was conducted in a $~ 90$-year-old naturally regenerated Pinus sylvestris forest in Rosinedalsheden experimental forest (64 $10^{\prime} \mathrm{N}, 19^{\circ} 45^{\prime} \mathrm{E}, 145 \mathrm{~m}$ a.s.1.), near Vindeln, Västerbotten, Sweden. The forest runs along the embankment of the Vindeln River, for approximately $4 \mathrm{~km}$, on generally flat topography, $40 \mathrm{~m}$ above the midsummer river surface. The 33-year mean annual temperature and precipitation (1981-2013), measured at the Svartberget field station $8 \mathrm{~km}$ from the study site, were $1.8^{\circ} \mathrm{C}$ and $614 \mathrm{~mm}$, respectively (Laudon et al., 2013). On average, the area is covered by snow from late October to early May. The soil is fine sand, and the profile formed is that of a weakly developed podzol with an organic mor layer ranging in thickness from 2 to $5 \mathrm{~cm}$.

The site was regenerated with $P$. sylvestris seed trees in $1920-1925$, pre-commercially thinned in 1955 and thinned in 1976 and 1993, respectively. The understory is covered by vegetation characterized by the dwarf shrubs, Vaccinium myrtillus (bilberry) and Vaccinium vitis-idaea (lingonberry), a ground layer of mosses, Pleurozium schreberi and Hylocomium splendens, and lichens, Cladonia spp. (Hasselquist et al., 2012).

Assuming N-limitation in the sandy soil, as reflected in the low $L$ and low volume production, the site was selected for quantifying the effect of $\mathrm{N}$-fertilization on net ecosystem C exchange (NEE) using the eddy covariance method. The designs of studies on the underlying mechanisms of the expected NEE response were constrained by the need to represent the un-replicated footprints of the eddy covariance systems. Thus, three pseudoreplicated mensuration plots $\left(1000 \mathrm{~m}^{2}\right.$ each) were established within the eddy covariance footprint of the treatment $(\mathrm{F})$ and the reference $(\mathrm{R})$ stands (each stand 13 ha and $\sim 2 \mathrm{~km}$ apart) to quantify stand-scale NPP of different biomass components, and $L$. An additional treatment mimicking an atmospheric $\mathrm{N}$-deposition of $2 \mathrm{~g} \mathrm{~N} \mathrm{~m}^{-2} \mathrm{yr}^{-1}$ was also established. We combined 


\section{H. Lim et al.}

data of trees harvested from this stand in 2006 with those from the R and the F stands to establish pre-treatment allometric functions, but otherwise focused our investigation on the latter two stands.

Frequent wind-induced tree-fall in the area permitted ample observations of how shallow the rooting system is. This was verified by digging the immediate root systems of trees and trenches between trees, showing a $<60 \mathrm{~cm}$ maximum depth for coarse roots (see Appendix). Consistent with this, fine roots nearly disappeared by a depth of $20 \mathrm{~cm}$. Published literature on P. sylvestris on sandy soils shows that of the fine roots found in the upper $30 \mathrm{~cm}, \sim 90 \%$ are in the $20 \mathrm{~cm}$ upper layer (Helmisaari et al., 2007; Hansson et al., 2013).

Fertilizer was applied to $\mathrm{F}$ at a rate of $10 \mathrm{~g} \mathrm{~N} \mathrm{~m}^{-2}$ annually in mid-June from 2006 through 2011, and $5 \mathrm{~g} \mathrm{~N} \mathrm{~m}^{-2} \mathrm{yr}^{-1}$ in 2012 and 2013, using Skog-Can fertilizer (Yara, Sweden), containing $\mathrm{NH}_{4}(13.5 \%), \mathrm{NO}_{3}(13.5 \%), \mathrm{Ca}(5 \%), \mathrm{Mg}(2.4 \%)$, and $\mathrm{B}(0.2 \%)$. Fertilization was administered in June each year reaching a total of $70 \mathrm{~g} \mathrm{~N} \mathrm{~m}^{-2}$ by 2013.

\subsection{Tree and stand measurements}

\subsubsection{Destructive harvests}

Destructive tree sampling was performed twice to capture the pre-treatment period and the time likely corresponding with stable treatment response. The first sampling was in early June 2006, thus representing biomass following the pre-treatment 2005 growing season. In October 2011, following six years of fertilization, six trees representing the range of tree diameter in the stands were harvested in each of the $\mathrm{R}$ and $\mathrm{F}$ stands. More detailed methodological information on the tree harvesting is presented in the Appendix.

\subsubsection{Foliar nutrients}




\section{H. Lim et al.}

To evaluate the effect of fertilization on the nutrient status of the trees in F compared to $\mathrm{R}$ stands, one-year-old needles were annually sampled in the upper third of the green crowns. This diagnostic sampling was made in late autumn or winter when starch reserves are depleted (cf. Linder 1995). After drying ( $85^{\circ} \mathrm{C}, 48 \mathrm{~h}$ ) the samples were ground in a ball mill (MM200, Retsch GmbH, Haan, Germany) and analyzed for C and N using an elemental analyzer (Flash EA 2000, Thermo Fisher Scientific). Other nutrient elements were analyzed with an inductively coupled plasma-optical emission spectrometry (ICP-OES) analyzer (Spectro Ciros Vision, SPECTRO Analytical Instruments GmbH, Germany).

In the harvest 2011, the green crowns of the twelve harvested trees were divided into five equal strata. Two representative branches from each stratum were taken for further processing. In the laboratory, the shoots of each sample branch were separated by age class ranging from current to four-year-old and the needles were removed from the shoots, dried, ground, and analyzed for $\mathrm{N}$ and $\mathrm{C}$.

\subsubsection{Mensuration and optical measurements}

Diameter at $1.3 \mathrm{~m}(\mathrm{DBH})$, height $(H)$, and length of the green crown $(\mathrm{LC})$ of trees in the mensuration plots were measured the first time after the growing season in August 2005. There were no measurements after the 2006 growing season, but thereafter the mensuration was made each year before (April - May) or after (October - November) the growing season. The DBH of all trees in each mensuration plot was measured using a caliper (Haglöf Inc., Sweden), and $H$ and LC were measured on 20 trees in each plot using Vertex 4 Ultrasonic Hypsometer (Haglöf Inc., Sweden). To estimate DBH increment during 2006 and 2007 the increment was partitioned between the two years based on the proportional increments observed in the tree ring data from the 2011 harvest. 


\section{H. Lim et al.}

The spring in 2013 and 2014 was warmer than normal and at the time of mensuration, some trees had already started to grow, which affected the estimate of the annual diameter increment for 2012 and 2013. In order to "correct" the estimates of DBH increment in 2012 and 2013, six increment cores representing the range of DBH were taken in July 2014, near each of the mensuration plots (18 cores in total). Annual basal area increments $(\Delta \mathrm{BA})$ in the two stands were weakly related to tree size (maximum $r^{2}=0.62$; minimum $\mathrm{P}<0.001$ ), but the relative $\Delta \mathrm{BA}\left(\triangle \mathrm{BA} / \mathrm{BA}\right.$ of the previous year) was unrelated to tree size (maximum $r^{2}=0.03$; minimum $\mathrm{P}=0.311)$ and was significantly higher in $\mathrm{F}(\mathrm{t}$-test, $\mathrm{P}<0.001)$. We employed the mean $\triangle \mathrm{BA} / \mathrm{BA}$ for estimating DBH in 2012 and 2013 of all trees in the mensuration plots.

Measurements of $H$ from the ground are subject to compensating errors among consecutive years; these measurements provide a reasonable estimate of periodic height increment, but are not particularly accurate for any year. We therefore relied on the mensuration data to provide height increment over the entire study period, infusing interannual dynamics obtained from trees harvested in 2011 and from trees that were wind thrown by a storm in late 2013 . These increases in annual height over the $2005-2013$, were divided by the total height increment $(\Delta H)$ over that period obtained from the mensuration measurements. The inter-annual ratio reflected inter-annual variation in growing season weather conditions, but not the effect of tree position in the canopy on $\Delta H$. We thus further employed the ratio of $\Delta H$ in each of the eight years based on the harvested and wind-thrown trees to the 60 trees annually measured for height (20 in each of the mensuration plots), and then regressed the adjusted tree $H$ to its $\mathrm{DBH}$, generating a $H$-DBH relationship for each treatment and year, and employed these relationships to estimate the heights of all trees in each plot.

Eleven litter traps $\left(0.5 \times 0.5 \mathrm{~m}^{2}\right)$ were established in each stand in June 2006. Litter fall was collected twice a year; before and after the period of intense needle shedding in autumn. 
H. Lim et al.

Litter was oven dried at $65^{\circ} \mathrm{C}$ and sorted into foliage, cones, bark, dead branches, and miscellaneous. The carbon concentration of litter was assumed to be 50\% (Mäkipää et al., 1999).

To estimate $L$ from canopy gap fraction, eleven hemispherical photographs were taken in the litter trap position in each stand at the time of the litter collection, using a Nikon Coolpix 900 digital camera and lens with a field view of $180^{\circ}$. The images were analyzed using HemiView 2.1 (Delta-T Devices, Cambridge, UK). Details of methods for data analysis of standing biomass and NPP of components, $L$ and $I_{C}$ are presented in the Appendix.

\subsection{Size-density baseline establishment}

To estimate relative stand density (RSD) of the study stands, we established a selfthinning baseline, i.e. the maximum size-density relationship for $P$. sylvestris at this location. We selected twelve stands representing a wide age range, all growing on sandy soil $<5 \mathrm{~km}$ from the experimental site, and displaying obvious signs of density-related mortality (i.e. undergoing self-thinning). Circular plots of $7-10$ m radius (increasing with age and decreasing tree density) were delineated and DBH of each tree was measured. The maximum size-density line was fitted (Yoda, 1963; White and Harper, 1970) as

$$
\log \overline{B A}=a \times \log S D+b
$$

where $\overline{B A}$ is the mean of basal area and SD is the number of trees per hectare or stand density. The line determines the maximum stand density for a given average tree basal area. The RSD of each experimental plot was calculated as the ratio of SD to maximum stand density and used as a covariate in analysis of response to the fertilization. 


\section{H. Lim et al.}

\subsection{Meteorological data}

For the growing seasons 2006 to 2013, daily mean temperature (thermistor: Cambell T107), precipitation (manually measured rain gauge, type Swedish Meteorological and Hydrological Institute), and global solar radiation (pyranometer: Kipp \& Zonen CM11) were obtained from the Svartberget field station located $8 \mathrm{~km}$ from the experimental site. Photosynthetically active radiation $(I)$ was calculated from global solar radiation by multiplying global solar radiation with the ratio 0.47 (Papaioannou et al., 1993). The growing season was defined to begin on the day after which daily mean temperature was $\geq 5{ }^{\circ} \mathrm{C}$ for at least five additional successive days, and the sum of daily mean temperature of the following five days was at least $15^{\circ} \mathrm{C}$, and end when daily mean temperature was below $<5^{\circ} \mathrm{C}$ for at least five successive days (Mäkelä et al., 2006).

\subsection{Statistical analyses}

After equality of variance was ascertained, treatment effects were evaluated based on two-sided t-test. Before testing whether relationship emerged between variables of interest, stand characteristics that might reflect unintended effects of pseudo-replication were included in analysis of covariance (ANCOVA) using standard least squares. Only after these stands characteristics were found to exert no interaction effects, did we employ General linear model (GLM) to derive relationships, and analysis of variance (ANOVA) using Tukey's test at (P = $0.05)$ to assess categorical effects and separate among means. All statistical tests were performed in JMP statistical software (ver. 10.0.0, SAS Institute Inc., Cary, NC). A detailed description of the approaches to estimating component standing biomass and net primary production, leaf area index, light interception, and foliage nutrient concentration is given in the Appendix. 


\section{Results}

From the recent 33 years of climate data (Laudon et al., 2013), growing season mean daily temperature $(T)$ and precipitation $(P)$ were $11.5^{\circ} \mathrm{C}$ and $325 \mathrm{~mm}$, respectively. The range of the long-term data was similar to that over the eight study years (Fig. 1).

\subsection{Allometric equations}

Coefficient of determination of the allometric equations of $\mathrm{R}$ trees in 2011 ranged from 0.66 to 0.99 (cone and foliage biomass, respectively,); and the P value from 0.03 to $<0.001$. Some of the basic results leading to estimation of standing biomass and $\mathrm{C}$ stock, and components of NPP are given in the Appendix (Table A1, A2). The lumped variable $\mathrm{DBH}^{2} \times$ $H$ was the best predictor for stem wood, bark volume, and coarse-root mass; $\mathrm{DBH} \times \mathrm{LC}$ for foliage mass, and DBH alone for branch and cone biomass (see Supplementary information Table S1).

\subsection{Stand production before the treatment}

To alleviate concerns that the response following the commencement of fertilization may be dominated by pre-treatment difference between the stands, owing to the pseudo-replicated nature of the study, we estimated size-related productivity from stem discs. Tree basal area increment $(1.3 \mathrm{~m})$ was correlated to tree basal area (Fig. 2a), and the relationships were similar in both stands $\left(y=228.22 x+1.84, r^{2}=0.93, \mathrm{P}<0.001, \mathrm{n}=12 ;\right.$ ANCOVA test, $\mathrm{P}=$ 0.838 for differences between slopes and $\mathrm{P}=0.209$ for difference between intercepts). Tree distribution in the R stand was shifted towards higher diameter than that in the F stand (Fig. $2 b$ ), confirming that if growth was different before the treatment commenced, it might have been slightly higher in the R stand. Our rough estimate of ANPP of the R stand was $27 \pm 10 \%$ higher $(\mathrm{P}=0.074)$ than that of the $\mathrm{F}$ stand prior to the treatment. We further evaluated 


\section{H. Lim et al.}

whether tree-to-tree competition was different between the stands before and during the study.

We generated a maximum size-density relationship, the so-called 'self-thinning line', from 12

stands (Fig. 2c; $\log \left[\right.$ trees $\left.\mathrm{ha}^{-1}\right]=-1.12 \log [$ mean tree basal area $]+1.98 ; r^{2}=0.80 ; \mathrm{P}<0.001$ ). The RSD of each plot (ranging among plots of $\mathrm{R}$ from 0.55 at the beginning of the study to 0.77 at the end, and from 0.46 to 0.68 at F) suggests that competition was higher in the $\mathrm{R}$ than the $\mathrm{F}$ stand at the beginning of the study $(\mathrm{P}=0.060$ in 2005). Thus, RSD was used as a covariate in the following ANOVA and GLM analyses, but was found not to contribute significantly to any of the statistical models (minimum $\mathrm{P}=0.413$ ), and did not change the outcome of the analyses.

\subsection{The effect of fertilization on foliage nutrients}

After two years of fertilization the needle concentration of $\mathrm{N}$ had increased by $46 \%$ and other macro-nutrients, except $\mathrm{Mg}$, were similar or higher in the fertilized than in the reference stand (Table A3). Boron, which was included in the fertilizer, had also increased and other micro-nutrients were well within recommended target values in relation to $\mathrm{N}$ (cf. Ingestad 1987; Linder, 1995). In the diagnostics samples 2011 the [N] of one-year-old needles was 95\% higher in $\mathrm{F}$ then $\mathrm{R}$, which was similar to what was found when sampling from different crown strata in October 2011 (Fig. 3, Table S3).

The 3-way interaction of foliage height, age, and treatment was insignificant $(\mathrm{P}=0.813)$. Foliage $[\mathrm{N}]$ was, however, higher with fertilization, and decreased faster with needle age class than in the R stand (Fig. 3; $\mathrm{n}=122$ and 142, in R and F, respectively; ANCOVA, interaction $\mathrm{P}<0.001)$. Foliage height singly or its interactions did not affect foliage $[\mathrm{N}]$ (minimum $\mathrm{P}=$ 0.452 for strata $\times$ age). Mean foliage $[\mathrm{N}]$ weighted by age and crown strata was 1.16 and $1.94 \%$ in $\mathrm{R}$ and $\mathrm{F}$, respectively $(\mathrm{n}=6$, t-test, $\mathrm{P}<0.001)$. In 2011, total amount of foliage $\mathrm{N}$ was higher in $\mathrm{F}$ (6.4 and $11.6 \mathrm{~g} \mathrm{~N} \mathrm{~m}^{-2}$ in $\mathrm{R}$ and $\mathrm{F}$, respectively, t-test, $\mathrm{P}<0.001$ ). 


\subsection{The effect of fertilization on stand dynamics}

Both stands reached a similar average RSD at the end of the study $(0.70$ and 0.62 for the $\mathrm{R}$ and F stands, respectively). Although still far from the self-thinning line, but within the range of imminent mortality caused by non-uniform spatial distribution of trees, beginning at RSD $=0.55$ (Drew and Flewelling, 1979). Mortality was observed in both stands during the last four years of the study at an average annual rate 0.33 and $0.28 \%$ in $\mathrm{R}$ and $\mathrm{F}$, respectively. These rates were slightly lower than expected based on competition alone $(0.5 \%$, Drew and Flewelling, 1977), indicating that neither stand was suffering from other causes of mortality.

\subsection{ANPP, NPP', L, and $I_{\mathrm{C}}$}

We examined general effects of fertilization on eight-year inter-annual variations of $L, I_{\mathrm{C}}$, ANPP, and NPP' (NPP excluding fine-roots and ectomycorrhizae (NPP $\mathrm{NR}_{\mathrm{F}}$ and $\left.\mathrm{NPP}_{\mathrm{EM}}\right)$, Fig.

4). The height increments $(\Delta H)$, were similar at both stands over the four years before fertilizing $\left(215 \mathrm{~mm} \mathrm{yr}^{-1} ; \mathrm{n}=6 ; \mathrm{P}=0.476\right)$, and were on average $60 \%$ higher in $\mathrm{F}$ over the eight year study period (210 vs. $304 \mathrm{~mm} \mathrm{yr}^{-1}$ in the $\mathrm{R}$ and $\mathrm{F}$, respectively, $\mathrm{n}=3$ plots, $\mathrm{t}$-test, $\mathrm{P}$ $<0.001$ ). Leaf area index $(L)$ was higher in $\mathrm{F}$ than in $\mathrm{R}$ from 2010 to 2013 (maximum $\mathrm{P}=$ 0.031; Fig. 4a), but $I_{\mathrm{C}}$ was similar during the entire study period (minimum $\mathrm{P}=0.081$; Fig. 4b). The highest fertilization-induced enhancement of growing season $I_{C}$ was $13 \%$ more than in the $\mathrm{R}$ stand ( 851 vs. $753 \mathrm{MJ} \mathrm{m}^{-2}$ ) in 2011 when $L$ was $31 \%$ higher in F compared to $\mathrm{R}(2.71$ vs. 2.08).

Although ANPP and NPP' of the first year following the treatment commencement was similar in both stands (minimum $\mathrm{P}=0.172$ ), the fertilization-induced enhancement reached significance in the second year (2007; maximum $\mathrm{P}=0.009$; Fig. 4c, d). In the last year of the 
H. Lim et al.

study, ANPP and NPP', respectively, were 27 and 28\% higher in the F stand (314 vs. 398 for ANPP and 338 vs. $433 \mathrm{~g} \mathrm{C} \mathrm{m}^{-2}$ for NPP', respectively; t-test, maximum $\mathrm{P}=0.005$ ).

\subsection{Interaction effects on $N P P^{\prime}$ and $N P P_{S}$ of stand and climate factors with fertilization}

The relationships of ANPP and NPP' with $I_{\mathrm{C}}$ and $L$, the slopes of which are indicative of light use efficiency and growth efficiency, respectively, were generated using the temporal variation in these quantities in each stand. The NPP' and ANPP were related to $L$ at both sites (maximum $\mathrm{P}=0.004$, Fig. 5). The $I_{\mathrm{C}}$ explained the inter-annual variation of ANPP or NPP' in $\mathrm{F}$ (not shown; maximum $\mathrm{P}=0.028$ ), but not in $\mathrm{R}$ (not shown; minimum $\mathrm{P}=0.807$ ).

We evaluated how well growing season $T$ and $P$ can explain the variation of NPP' and $\mathrm{NPP}_{\mathrm{S}}$ (Fig. 6). In both stands, production of stem wood was $63.8 \pm 4.2 \%$ of $\mathrm{NPP}_{\mathrm{S}}$. The two production variables were related to $T$ in both stands, with similar slopes but different intercepts (see ANCOVA results, Table 1). The difference between the intercepts of NPP' and $\mathrm{NPP}_{\mathrm{S}}$ were 108 and $70 \mathrm{~g} \mathrm{C} \mathrm{m}^{-2} \mathrm{yr}^{-1}$, respectively. Large residuals remained from the linear regression fits for data from the F stand (Fig. 6a, b); much of the variation of these residuals in F was explained by the inter-annual variation of $P$ (Fig. 6c, d). No $T \times P$ interaction was observed in this study $(\mathrm{P}=0.964)$.

\section{Discussion}

Patterns in foliage nutrient concentration often provide a good indication of soil nutrient availability and limitations even where soil nutrient analyses fail to do so (e.g. Timmer and Morrow, 1984; Ingestad, 1987; Linder, 1995). Stands growing on sandy soils often suffer from nutrient limitation, clearly reflected in low canopy $L$, low nutrient concentration in foliage, and strong response to fertilization (Vose and Allen, 1988; Albaugh et al., 1998; Albaugh et al., 2004; Maier et al., 2004). The production in Nordic boreal forests is almost without exceptions limited by soil $\mathrm{N}$ availability (e.g.Tamm, 1991; Jarvis and Linder, 2000). 


\section{H. Lim et al.}

Our analysis showed that $\mathrm{N}$-fertilization reduced $\mathrm{N}$-limitation and increased biomass production without negative effects on other essential nutrient elements (Table A3). The response to the fertilization during the studied period was similar to that of $P$. sylvestris sites included in Carl-Olof Tamm's series of long-term “Optimum nutrition experiments" (Tamm, 1991; Tamm et al., 1999). Among the various treatments at these sites, those similar to our study resulted in similar foliage nutrient concentrations and biomass production, while providing only $\mathrm{P}$ and $\mathrm{K}$ had no effect on biomass production, demonstrating that the production was primarily controlled by low soil $\mathrm{N}$ availability (Tamm et al., 1999). We thus considered the stands in the area $\mathrm{N}$ limited, and the response to fertilization to reflect alleviation from such growth limitation.

All estimated components of biomass production showed response to fertilization soon after the commencement of the treatment, indicating both the capacity of mature $P$. sylvestris stands to respond to changing resource availability, as well as the severe $\mathrm{N}$-limitation under which the stand was growing (Fig. 4c, d). Although such response has been observed before in similar stands (Tamm, 1991; Valinger, 1993; Nilsen and Abrahamsen, 2003; Jacobson and Pettersson, 2010) and in other mature conifer and broadleaved plantations (Linder et al., 1987; Vose and Allen, 1988; Giardina et al., 2003; Albaugh et al., 2004; Allen et al., 2005; Coyle et al., 2008; Campoe et al., 2013), less common is the observation that production is sensitive to growing season temperature (Peltola et al., 2002; Way and Oren, 2010). Such sensitivity is not surprising considering the relatively low growing season temperature (Fig. 7a) and the response of photosynthetic rate of $P$. sylvestris to temperature (Linder and Troeng, 1980; Wang et al., 1995; Strand et al., 2002; Hari and Mäkelä, 2003). However, the effect of increased temperature on production may not always be positive. In the warm-moist temperate region of southern US, three of the four dominating southern pine species (Coile, 1936) and several other conifer and broadleaved species cited therein, decreased in growth 


\section{H. Lim et al.}

with increasing temperature during key months of the growing season. Indeed, the response of production to temperature may depend on the prevailing growth temperature, decreasing when the prevailing temperature is high and increasing where it is low (Way and Oren, 2010). Furthermore, nutrient limitation may be so severe that it overrides the temperature effect on growth of boreal forest species; for example, growing on nutrient-poor till, mature Picea abies trees warmed in large chambers did not respond to increased air temperature (Sigurdsson et al., 2013). This is consistent with a steeper slope of photosynthetic response to temperature in fertilized $P$. sylvestris relative to less responsive unfertilized trees growing on nutrient-poor soil (Kellomäki et al., 1982).

Although both photosynthetic rate and production of $\mathrm{N}$-fertilized stands may be more responsive to changes in temperature than stands growing under severe nutrient limitations, in contrast to our hypothesized interaction effect (H3a), this was not the case since the sensitivity of both stands to growing season temperature was similar (Fig. 6a, b). However, the NPP response to fertilization depended also on moisture availability (Fig. 6c, d). Although many studies show that growth increases with water availability (or surrogates of water availability such as precipitation or drought indices; e.g., Coile, 1936), there are few observation showing that, once N-limitation was alleviated, growing season water availability can limit production. More common is the observation that absolute and relative growth responses to fertilization are variable among years, and that the variation is higher in coarse-texture soils holding less water, and in sites that can suffer drought (Nilsen and Abrahamsen, 2003; Borders et al., 2004; Jacobson and Pettersson, 2010). Moreover, our results are consistent with observations from factorial irrigation $\times$ fertilization studies showing that inter-annual variation in production increased with nutrient additions and decreased with irrigation, especially in the south of Sweden where early summer droughts are common (Bergh et al. 1999; Tamm et al. 1999). Indeed, carbon isotope studies revealed that fertilized stands show increased 


\section{H. Lim et al.}

susceptibility to drought with increasing $\mathrm{N}$ availability (Betson et al., 2007), probably caused by an increased $L$, greater reduction in stomatal conductance in dry years (Högberg et al., 1993), and increased loss of foliage during severe droughts (Albrektson, 1988). Thus, we find that in P. sylvestris stands growing on unfertile sandy soil of low moisture holding capacity, NPP response to N-fertilization can be nearly nullified in dry years (Fig. 6c, d), consistent with the interaction response of NPP to fertilization and precipitation $(\mathrm{H} 3 \mathrm{~b})$. We note that such conditions represent $60 \%$ of $\sim 1.1 \times 10^{6} \mathrm{~km}^{2}$ of this species (Jalas and Suominen, 1972; Nikolov and Helmisaari, 1992; Brady and Weil, 2010) and even greater area considering all pines on such soils.

Soil water availability in both our stands is limited by shallow rooting depth $(\sim 60 \mathrm{~cm})$ and low moisture holding capacity of the sandy soil. Studies on pines growing on sandy soils showed that hydraulic adjustments allow trees in fertilized stands to draw soil moisture to lower levels by producing tissues that are less sensitive to cavitation (Ewers et al., 2000). This way trees may be able to sustain lower water potentials which may increase leaf-specific hydraulic conductivity and stomata conductance, but increases of $L$ will lower the ratios of sapwood-to-leaf area and root-to-leaf area, which operate to decrease leaf-specific conductivity (Whitehead et al., 1984; Ewers et al., 2000; Hacke et al., 2000). Thus, although sustained soil moisture limitations is typically reflected for shorter trees in open stands (Ewers et al., 2001; Addington et al., 2006), fertilizing such stands may increase $L$ and water use beyond that sustainable in severe drought years (Choi et al., 2005), resulting in large amount of foliage loss during dry years with corresponding effects on growth (Linder, 1987; Linder et al. 1987; Albrektson, 1988).

Although the nature of the study, pseudo-replicated plots within the eddy covariance footprints, resulted in initial conditions not being the same in the fertilized and reference stands, we found that stand density and average tree size, combined to relative stand density 


\section{H. Lim et al.}

were higher in $\mathrm{R}$ than $\mathrm{F}$, but converged soon after the fertilization commenced (Fig. 2c). Thus relative stand density was not a useful covariate in analyses of fertilization effects. Based on tree-ring analyses, production in $\mathrm{F}$ was not higher than that of $\mathrm{R}$ before the treatment initiated; tree basal area increment was correlated to tree size similarly in both stands; tree distribution tended towards greater size in R (Fig. 2a, b); height growth was similar. Indeed, when the study began, production was similar in both stands in the first year after fertilization commenced.

Without $\mathrm{N}$ addition, average NPP of stem wood over the eight-year study was $0.23 \mathrm{~kg} \mathrm{C}$ $\mathrm{m}^{-2}$ of dry mass, similar to other similar stands $\left(0.22 \mathrm{~kg} \mathrm{C} \mathrm{m}^{-2}\right.$ in Helmisaari et al., 2002 and $0.24 \mathrm{~kg} \mathrm{C} \mathrm{m}^{-2}$ in Xiao et al., 2003). In 2011, when canopy [N] in the F stand was $67 \%$ higher (Fig. 3) and $I_{\mathrm{C}} 13 \%$ higher than in the R stand (Fig. 4b), ANPP reached its maximum enhancement, 93\% higher than in R (Fig. 4c). This relative response is similar to that of a tropical Eucalyptus saligna plantation (85\%, Giardina et al., 2003), and a temperate, warmmoist Pinus taeda plantation (98\%, Maier et al., 2004). For long-term biomass components (woody components of which stem wood comprises $\sim 64 \%$, see Table A2), fertilization increased $\mathrm{NPP}_{\mathrm{S}}$ by $70.2 \mathrm{~g} \mathrm{C} \mathrm{m}^{-2} \mathrm{yr}^{-1}$ relative to $\mathrm{R}$ over the entire inter-annual range of growing season temperature (Fig. 6b), suggesting that higher temperature did not enhance nutrient availability, representing a response inconsistent with the hypothesized fertilization $\times$ temperature interaction $(\mathrm{H} 3 \mathrm{a})$.

We explained a total 58 and $83 \%$ of the variance of $\mathrm{NPP}_{\mathrm{S}}$ in $\mathrm{R}$ and $\mathrm{F}$, respectively, using temperature and precipitation (Table 1$)$. Considering the slow growth in $\mathrm{R}(0.16 \mathrm{~cm}$ per year of mean increment in DBH over eight years), annual measurement errors would easily introduce a random variance reducing the ability to explain the total variance in that stand (Castagneri et al., 2012). This was less of an issue in the F stand that grew faster $(0.34 \mathrm{~cm}$ per year, Table A1). Explaining the variability of diameter increment, Coile (1936) and 


\section{H. Lim et al.}

Skomarkova et al. (2006) accounted for 20 and 17\%, respectively, based on temperature, and 30 and $6 \%$, respectively, based on precipitation. Considering the higher growth rate in the moist southern US region (Coile, 1936) and Germany (Skomarkova et al., 2006), our results are not unusually low.

Next we assess whether the increase in production observed under fertilization is supported by increased GPP, altered C partitioning, or both. The increment of $I_{\mathrm{C}}$ with fertilization was small (Fig. 4b) because, although $L$ (and foliage mass) increased with fertilization (Fig. 4a), the difference from $\mathrm{R}$ was small, possibly due to water limitations (Linder et al., 1987; Vose and Allan 1988), coupled with an expected saturation of $I_{\mathrm{C}}$ with $L$ (Eq. (3)). The estimated value for the effective extinction coefficient $(k)$ was $\sim 0.59$ and similar to other $P$. sylvestris stands estimated based on the ratio of mean shoot silhouette area to projected needle area ( 0.6 calculated from Stenberg et al., 2001). Although we used the same $k$ for both treatments, fertilization-induced increase of $k$ could have potentially increased $I_{\mathrm{C}}$. However, studies on $P$. abies suggest that fertilization has no effect on shoot structure (Palmroth et al., 2002), which is the primary determinant of $k$. Thus, fertilization generated a small increase of $L$ with little effect on light absorption, which should result in only small increase of GPP. Consistent with this conclusion, the 9\% higher foliage biomass in F should translate to only $30 \mathrm{~g} \mathrm{C} \mathrm{m}^{-2} \mathrm{yr}^{-1}$ or $3 \%$ higher GPP relative to $\mathrm{R}$ based on a relationship available for this region (Härkönen et al., 2010).

We further searched for an indication of changed $\mathrm{C}$ partitioning as supporting the increase of ANPP and NPP' under fertilization. Our most complete data for such analysis were from 2012 during which fine-root biomass was estimated. One potential major component of belowground production was not estimated in this study - extrametrical hyphae of ectomycorrhizal fungi. We estimated NPP of ectomycorrhizae $\left(\mathrm{NPP}_{\mathrm{EM}}\right)$ based on the ratio of ectomycorrhiza-to-root respiration multiplied by fine-root NPP ( $\mathrm{NPP}_{\mathrm{FR}}$, Table 2). Despite 


\section{H. Lim et al.}

some increase of $\mathrm{C}$ used in coarse-root NPP with fertilization, a greater proportional reduction in $\mathrm{NPP}_{\mathrm{FR}}$ and $\mathrm{NPP}_{\mathrm{EM}}$, a large flux, resulted in a $36 \%$ lower BNPP in the $\mathrm{F}$ stand. This is similar to N-fertilization induced reduction of soil respiration found at a boreal $P$. abies forest (40\%, Olsson et al., 2005). Moreover, considering that total NPP in R and F were similar (519 vs. $505 \mathrm{~g} \mathrm{C} \mathrm{m}^{-2}$ ), consistent with a similarity of GPP, the increase of ANPP in F, mostly in woody biomass, was accomplished by the shift of $\sim 85 \mathrm{~g} \mathrm{C} \mathrm{m}^{-2}$ from below- to aboveground. Thus, in contrast to $\mathrm{H} 1$, but consistent with $\mathrm{H} 2$, fertilization-induced increase of ANPP was not caused by increased light interception or photosynthetic rates, but rather by a $17 \%$ increased $\mathrm{C}$ partitioning to aboveground at the expense of belowground with NPP remaining unchanged.

We note that, although in nutrient limited stands, fine-roots last longer than those in fertile stands (Leppälammi-Kujansuu et al. 2014b) to reduce nutrient loss via mortality (Ahlström et al., 1988; Persson and Ahlström, 1990), a higher proportion of these fine roots are infected with mycorrhizae (Arnebrant and Söderström, 1992), playing a role in protecting fine-roots from pathogens (Schoettle and Fahey, 1994). However, a higher biomass of mycorrhizal fungi in unfertilized stands (Hasselquist et al., 2012), together with rapid turnover of fungal hyphae, and a 50\% larger crop of standing, respiring fine root biomass (Table 2) promotes a higher $\mathrm{C}$ partitioning belowground in unfertilized than fertilized stands (Palmroth et al., 2006; Hasselquist et al., 2012; Oishi et al., 2014).

We do not have sufficient data, especially on $\mathrm{NPP}_{\mathrm{FR}}$, to assess the effects of inter-annual variation in weather conditions on $\mathrm{C}$ allocation. However, the large variations of several NPP components found with temperature in both $\mathrm{N}$ regimes, and the additional variation found with precipitation under high $\mathrm{N}$ availability (Fig. 6), are not likely to be explainable by corresponding variations of GPP and thus total NPP. This, coupled with the NPP budget in 


\section{H. Lim et al.}

2012 and its response to fertilization, suggests that climate-induced inter-annual variation in C partitioning should be investigated in the context of ANPP and $\mathrm{NPP}_{\mathrm{S}}$ response to fertilization.

\section{Management implications}

The response of $P$. sylvestris forests to long-term repeated fertilization may continue for more than 30 years both in terms of tree growth (Bergh et al., 2014) and understory (Strengbom et al., 2001; Strengbom and Nordin, 2012). Thus, assessing the sensitivity of the response to climate variability where long-rotation silviculture dominates is highly relevant to managers who must justify allocating limited resources to maximize wood production over periods in which changes in climate conditions are quite certain. The consequence of the relationships shown in Fig. 6 is that fertilization-induced enhancement of NPP at the site increases with growing season precipitation at all growing season temperatures. At the mean growing season temperature during the recent 33 years, $\mathrm{NPP}_{\mathrm{S}}$ enhancement of $\mathrm{F}$ relative to $\mathrm{R}$ ranged from only 1.1 to as high as 1.7 (Fig. 7c) with precipitation ranging 307 to $420 \mathrm{~mm}$ (Fig. 1), the range observed during the study period. Projecting just slightly out of the range observed during the study period to precipitation of $294 \mathrm{~mm}$, only $31 \mathrm{~mm}$ below the 33-year average but within the longer-term record (Fig. 7a), at a year of the long-term mean temperature $\left(11.5^{\circ} \mathrm{C}\right.$; Fig. $\left.7 \mathrm{a}\right)$, the effect of fertilization on stand production will be nullified. On the other hand, at the same temperature, precipitation of $\sim 434 \mathrm{~mm}$, or $109 \mathrm{~mm}$ above the average should result in doubling production of fertilized stands relative to unfertilized stands. Over the recent 33 years, precipitation $<294 \mathrm{~mm}$ was observed 12 times, while those of $>434$ mm were observed only three times (Fig. 7b).

Regardless of future climate changes, our findings that the relative sensitivity of fertilization-induced NPP enhancement increases as growing season temperature approaches the minimum observed, and decreases as it approaches the maximum observed (Fig. 7c), may 


\section{H. Lim et al.}

serve to explain the large inter-annual variation of growth response to fertilization that has been observed in boreal $P$. sylvestris forests (Bergh et al., 2014). Furthermore, models predict future increases in both annual mean temperature (averaging $4{ }^{\circ} \mathrm{C}$ in 50 years) and precipitation (20\%) in northern Sweden (Rummukainen et al., 2009). Estimating the response of $\mathrm{NPP}_{\mathrm{S}}$ to a period with climate identical to the past 33-year record based on the relationships we developed, the fertilization-induced increase of mean annual $\mathrm{NPP}_{\mathrm{S}}$ would be $40 \%$ (with $42 \%$ standard deviation of the inter-annual response). The predicted change in climate (assuming a strict increase of $4{ }^{\circ} \mathrm{C}$ and $20 \% \mathrm{P}$ in all 33 growing seasons) increased the relative enhancement of $\mathrm{NPP}_{\mathrm{S}}$ to $45 \%$ (standard deviation $35 \%$ ) due to reduction in water stress. If such a future prevails, the response to fertilization should be greater. We note, however, that predictions of growing season climate conditions are much more uncertain than prediction of annual climate conditions, and that predictions of precipitation regimes are fraught with uncertainty (Rummukainen et al., 2009). We also note that our analyses need replicating in other studies to assess its generality.

Adaptive forest management progressively gains ground, and so is the need for regular reassessment of stand management regimes. Information such as that developed here, together with improved predictions of future climate, will reduce uncertainty of assessment of benefits from fertilization and other silvicultural practices, relevant to establishing adaptation strategies and practical actions in the future (Millar et al., 2007; Janowiak et al., 2014). 
H. Lim et al.

\section{Acknowledgements}

The Rosinedalsheden research site was established with support from the Kempe Foundation and the Swedish Research Council for Environment, Agricultural Sciences and Spatial Planning, (FORMAS) and is since 2014 part of the "Swedish Infrastructure for Ecosystem Science" (SITES) sponsored by the Swedish Science Foundation (VR). This study received support from the research programs "Future Forests" (Swedish Foundation for Strategic Environmental -MISTRA), "Trees and Crops for the Future” (Swedish Governmental Agency for Innovation Systems - VINNOVA) and "Nitrogen and Carbon in Forests" (FORMAS). Ram Oren was sponsored by the United States Department of Agriculture through the Agriculture and Food Research Initiative (2011-67003-30222), and Department of Energy through the Office of Biological and Environmental Research, Terrestrial Ecosystem Science program (DE-SC0006967), and Sari Palmroth was partially sponsored by DOE-BER, TES (DE-SC-0006700-11-ER65189). We specially thank Svartberget field station for providing meteorological data and staff for fieldwork. 
H. Lim et al.

\section{References}

Addington, R.N., Donovan, L.A., Mitchell, R.J., Vose, J.M., Pecot, S.D., Jack, S.B., Hacke, U.G., Sperry, J.S., Oren, R., 2006. Adjustments in hydraulic architecture of Pinus palustris maintain similar stomatal conductance in xeric and mesic habitats. Plant Cell Environ. 29, 535-545. doi: 10.1111/j.1365-3040.2005.01430.x

Ahlström, K., Persson, H., Börjesson, I., 1988. Fertilization in a mature Scots pine (Pinus sylvestris L.) stand—effects on fine roots. Plant Soil. 106, 179-190. doi: 10.1007/BF02371212

Albaugh, T.J., Allen, H.L., Dougherty, P.M., Kress, L.W., King, J.S., 1998. Leaf area and above- and belowground growth responses of loblolly pine to nutrient and water additions. For. Sci. 44, 317-328.

Albaugh, T.J., Allen, H.L., Dougherty, P.M., Johnsen, K.H., 2004. Long term growth responses of loblolly pine to optimal nutrient and water resource availability. For. Ecol. Manage. 192, 3-19. doi: 10.1016/j.foreco.2004.01.002

Albrektson, A., 1988. Needle litterfall in stands of Pinus sylvestris L. in Sweden, in relation to site quality, stand age and latitude. Scand. J. For. Res. 3, 333-342. doi:

$10.1080 / 02827588809382521$

Allen, C.B., Will, R.E., Jacobson, M.A., 2005. Production efficiency and radiation use efficiency of four tree species receiving irrigation and fertilization. For. Sci. 51, 556-569.

Arnebrant, K., Söderström, B., 1992. Effects of different fertilizer treatments on ectomycorrhizal colonization potential in two Scots pine forests in Sweden. For. Ecol. Manage. 53, 77-89. doi: 10.1016/0378-1127(92)90035-8

Avery, T.E., Burkhart, H.E., 1983. Forest measurements. McGraw-Hill Book Company, New York.

Axelsson, E., Axelsson, B., 1986. Changes in carbon allocation patterns in spruce and pine 


\section{H. Lim et al.}

trees following irrigation and fertilization. Tree Physiol. 2, 189-204.

Bergh, J., Linder, S., Lundmark, T., Elfving, B., 1999. The effect of water and nutrient availability on the productivity of Norway spruce in northern and southern Sweden. For. Ecol. Manage. 119: 51-62

Bergh, J., Linder, S., Bergström, J., 2005. Potential production of Norway spruce in Sweden. For. Ecol. Manage. 204, 1-10. doi: 10.1016/j.foreco.2004.07.075

Bergh, J., Nilsson, U., Allen, H.L., Johansson, U., Fahlvik, N., 2014. Long-term responses of Scots pine and Norway spruce stands in Sweden to repeated fertilization and thinning. For. Ecol. Manage. 320, 118-128. doi: 10.1016/j.foreco.2014.02.016

Betson, N.R., Johannisson, C., Ottosson Löfvenius, M., Grip, H., Granström, A., Högberg, P., 2007. Variation in the $\delta^{13} \mathrm{C}$ of foliage of Pinus sylvestris L. in relation to climate and additions of nitrogen: analysis of a 32-year chronology. Global Change Biol. 13, 23172328. doi: 10.1111/j.1365-2486.2007.01431

Borders, B.E., Will, R.E., Markewitz, D., Clark, A., Hendrick, R., Teskey, R.O., Zhang, Y., 2004. Effect of complete competition control and annual fertilization on stem growth and canopy relations for a chronosequence of loblolly pine plantations in the lower coastal plain of Georgia. For. Ecol. Manage. 192, 21-37. doi: 10.1016/j.foreco.2004.01.003

Brady, N.C., Weil, R.R., 2010. Elements of the Nature and Properties of Soils, 2nd edn. Pearson Prentice Hall, New Jersey, pp. 58-93

Campoe, O.C., Stape, J.L., Albaugh, T.J., Allen, H.L., Fox, T.R., Rubilar, R., Binkley, D., 2013. Fertilization and irrigation effects on tree level aboveground net primary production, light interception and light use efficiency in a loblolly pine plantation. For. Ecol. Manage. 288, 43-48. doi: 10.1016/j.foreco.2012.05.026

Castagneri, D., Nola, P., Cherubini, P., Motta, R., 2012. Temporal variability of size-growth relationships in a Norway spruce forest: the influences of stand structure, logging, and 


\section{H. Lim et al.}

climate. Can. J. For. Res. 42, 550-560. doi: 10.1139/X2012-007

Choi, W.J., Chang, S.X., Allen, H.L., Kelting, D.L., Ro, H.-M., 2005. Irrigation and fertilization effects on foliar and soil carbon and nitrogen isotope ratios in a loblolly pine stand. For. Ecol. Manage. 213, 90-101. doi: 10.1016/j.foreco.2005.03.016

Coile, T.S., 1936. The effect of rainfall and temperature on the annual radial growth of pine in the southern United States. Ecol. Monogr. 6, 533-562. doi: 10.2307/1943241

Colbert, S.R., Jokela, E.J., Neary, D.G., 1990. Effects of annual fertilization and sustained weed-control on dry-matter partitioning, leaf-area, and growth efficiency of juvenile loblolly and slash pine. For. Sci. 36, 995-1014.

Coyle, D.R., Coleman, M.D., Aubrey, D.P., 2008. Above- and below-ground biomass accumulation, production, and distribution of sweetgum and loblolly pine grown with irrigation and fertilization. Can. J. For. Res. 38, 1335-1348. doi: 10.1139/X07-231

Cromer, R.N., Jarvis, P.G., 1990. Growth and biomass partitioning in Eucalyptus grandis seedlings in response to nitrogen supply. Aust. J. Plant Physiol. 17, 503-515.

Cummings, N.H.O., 1972. Heartwood differentiation in Pinus species-a modified azo-dye test. NZ. J. For. Sci. 2, 188-191.

Drew, T.J., Flewelling, J.W., 1977. Some recent Japanese theories of yield-density relationships and their application to Monterey pine plantations. For. Sci. 23, 517-534.

Drew, T.J., Flewelling, J.W., 1979. Stand density management - an alternative approach and its application to Douglas-fir plantations. For. Sci. 25, 518-532.

Ericsson, T., Rytter, L., Vapaavouri, E., 1996. Physiology of carbon allocation in trees. Biomass Bioenergy 2/3, 115-127.

Ewers, B.E., Oren, R., Sperry, J.S., 2000. Influence of nutrient versus water supply on hydraulic architecture and water balance in Pinus taeda. Plant Cell Environ. 23, 10551066. doi: 10.1046/j.1365-3040.2000.00625.x 
H. Lim et al.

Ewers, B.E., Oren, R., Phillips, N., Strömgren, M., Linder, S., 2001. Mean canopy stomatal conductance responses to water and nutrient availabilities in Picea abies and Pinus taeda. Tree Physiol. 21, 841-850. doi: 10.1093/treephys/21.12-13.841

Flower-Ellis, J., Persson, H., 1980. Investigation of structural properties and dynamics of Scots pine stands. Ecol. Bull. (Stockholm). 32, 125-138. doi: 10.2307/20112806

Franklin, O., Högberg, P., Ekblad, A., Ågren, G.I., 2003. Pine forest floor carbon accumulation in response to $\mathrm{N}$ and $\mathrm{PK}$ additions: bomb ${ }^{14} \mathrm{C}$ modelling and respiration studies. Ecosystems 6, 644-658. doi: 10.1007/s10021-002-0149-x

Fries, A., Ruotsalainen, S., Lindgren, D., 1998. Effects of temperature on the site productivity of Pinus sylvestris and lodgepole pine in Finland and Sweden. Scand. J. For. Res. 13, 128-140.

Giardina, C.P., Ryan, M.G., Binkley, D., Fownes, J.H., 2003. Primary production and carbon allocation in relation to nutrient supply in a tropical experimental forest. Global Change Biol. 9, 1438-1450. doi: 10.1046/j.1365-2486.2003.00558.x

Hacke, U.G., Sperry, J.S., Ewers, B.E., Ellsworth, D.S., Schäfer, K.V.R., Oren, R., 2000. Influence of soil porosity on water use in Pinus taeda. Oecologia 124, 495-505. doi: 10.1007/PL00008875

Halldin, S., 1985. Leaf and bark area distribution in a pine forest. In: Hutchison, B.A., Hicks, B.B. (Eds.), The Forest-Atmosphere Interaction. Springer Netherlands, pp. 39-58.

Hansson, K., Helmisaari, H.S., Sah, S.P., Lange, H., 2013. Fine root production and turnover of tree and understorey vegetation in Scots pine, silver birch and Norway spruce stands in SW Sweden. For. Ecol. Manage. 309, 58-65. doi: 10.1016/j.foreco.2013.01.022

Hari, P., Mäkelä, A., 2003. Annual pattern of photosynthesis in Scots pine in the boreal zone. Tree Physiol. 23, 145-155. doi: 10.1093/treephys/23.3.145

Hasselquist, N.J., Högberg, P., Metcalfe, D.B., 2012. Contrasting effects of low and high 
H. Lim et al.

nitrogen additions on soil $\mathrm{CO}_{2}$ flux components and ectomycorrhizal fungal sporocarp production in a boreal forest. Global Change Biol. 18, 3596-3605. doi:

$10.1111 /$ gcb. 12001

Haxeltine, A., Prentice, I.C., 1996. A general model for the light-use efficiency of primary production. Funct. Ecol. 10, 551-561. doi: 10.2307/2390165

Haynes, B.E., Gower, S.T., 1995. Belowground carbon allocation in unfertilized and fertilized red pine plantations in northern Wisconsin. Tree Physiol. 15, 317-325. doi:

10.1093/treephys/15.5.317

Härkönen, S., Pulkkinen, M., Duursma, R., Mäkelä, A., 2010. Estimating annual GPP, NPP and stem growth in Finland using summary models. For. Ecol. Manage. 259, 524-533. doi: 10.1016/j.foreco.2009.11.009

Helmisaari, H.S., Makkonen, K., Kellomäki, S., Valtonen, E., Mälkönen, E., 2002. Belowand above-ground biomass, production and nitrogen use in Scots pine stands in eastern Finland. For. Ecol. Manage. 165, 317-326. doi: 10.1016/S0378-1127(01)00648-X

Helmisaari, H.S., Derome, J., Nöjd, P., Kukkola, M., 2007. Fine root biomass in relation to site and stand characteristics in Norway spruce and Scots pine stands. Tree Physiol. 27, $1493-1504$.

Högberg, P., Johannisson, C., Hällgren, J.-E., 1993. Studies of ${ }^{13} \mathrm{C}$ in the foliage reveal interactions between nutrients and water in forest fertilization experiments. Plant Soil 152, 207-214. doi: 10.1007/BF00029090

Ilvesniemi, H., Liu, C., 2001. Biomass distribution in a young Scots pine stand. Boreal Environ. Res. 6, 3-8.

Ingestad, T., 1987. New concepts on soil fertility and plant nutrition as illustrated by research on forest trees and stands. Geoderma, 40, 237-252. 


\section{H. Lim et al.}

Ingestad, T., Ågren, G.I., 1991. The influence of plant nutrition on biomass allocation. Ecol. Appl. 1, 168-174.

Jacobson, S., Pettersson, F., 2010. An assessment of different fertilization regimes in three boreal coniferous stands. Silva Fenn. 44, 815-827.

Jalas, J., Suominen, J., 1972. Atlas Florae Europaeae: Distribution of Vascular Plants in Europe. 1: Pteriophyta (Psilotaceae to Azollaceae). Akateeminen Kirjakaupa.

Janowiak, M.K., Swanston, C.W., Nagel, L.M., Brandt, L.A., Butler, P.R., Handler, S.D., Shannon, P.D., Iverson, L.R., Matthews, S.N., Prasad, A., Peters, M.P., 2014. A practical approach for translating climate change adaptation principles into forest management actions. J. For. 112, 424-433. doi: 10.5849/jof.13-094

Janssens, I.A., Sampson, D.A., Cermak, J., Meiresonne, L., Riguzzi, F., Overloop, S., Ceulemans, R., 1999. Above- and belowground phytomass and carbon storage in a Belgian Scots pine stand. Ann. For. Sci. 56, 81-90. doi: 10.1051/forest:19990201

Kellomäki, S., Puttonen, P., Tamminen, H., Westman, C.J., 1982. Effect of nitrogen fertilization on photosynthesis and growth in young Scots pines. Silva Fenn. 16, 363-371.

Kim, H.-S., Palmroth, S., Therezien, M., Stenberg, P., Oren, R., 2011. Analysis of the sensitivity of absorbed light and incident light profile to various canopy architecture and stand conditions. Tree Physiol. 31, 30-47. doi: 10.1093/treephys/tpq098

Knapp, A.K., Smith, M.D., 2001. Variation among biomes in temporal dynamics of aboveground primary production. Science 291, 481-484. doi:

10.1126/science.291.5503.481

Kukkola, M., Saramäki, J., 1983. Growth response in repeatedly fertilized pine and spruce stands on mineral soils. Comm. Inst. For. Fenn. 114, 1-155.

Laudon, H., Taberman, I., Ågren, A., Futter, M., Ottosson Löfvenius, M., Bishop, K., 2013. The Krycklan catchment study—a flagship infrastructure for hydrology, biogeochemistry, 
H. Lim et al.

and climate research in the boreal landscape. Water Resour. Res. 49, 7154-7158. doi:

$10.1002 /$ wrcr. 20520

Law, B.E., Ryan, M.G., Anthoni, P.M., 1999. Seasonal and annual respiration of a ponderosa pine ecosystem. Global Change Biol. 5, 169-182. doi: 10.1046/j.1365-2486.1999.00214.x

Lee, K.-H., Jose, S., 2003. Soil respiration, fine root production, and microbial biomass in cottonwood and loblolly pine plantations along a nitrogen fertilization gradient. For. Ecol. Manage. 185, 263-273. doi: 10.1016/S0378-1227(03)00164-6

Leppälammi-Kujansuu, J., Aro, L., Salemaa, M., Kleja, D.B., Hansson, K., Helmisaari, H-S., 2014a. Fine root longevity and carbon input into soil from below- and aboveground litter in climatically contrasting forests. For Ecol. Manage. 326,79-90. doi:

10.1016/j.foreco.2014.03.039

Leppälammi-Kujansuu, J., Helmisaari, H.S., Linder, S., Salemaa, M., Kleja, D.B., 2014b.

Fine root turnover and litter production of Norway spruce in a long-term temperature and nutrient manipulation experiment. Plant Soil 374, 73-88. doi: 10.1007/s11104-013-18533

Linder, S., 1987. Responses to water and nutrients in coniferous ecosystems, In: Potential and Limitations of Ecosystem Analysis. Schulze, E.-D., Zwölfer, H. (Eds.), Ecological Studies. Springer Berlin Heidelberg, pp. 180-202.

Linder, S., 1995. Foliar analysis for detecting and correcting nutrient imbalances in Norway spruce. Ecol. Bull. (Copenhagen). 44, 178-190. doi: 10.2307/20113161

Linder, S., Troeng, E., 1980. Photosynthesis and transpiration of 20-year-old Scots pine. Ecol. Bull. (Stockholm). 32, 165-181. doi: 10.2307/20112809

Linder, S., Axelsson, B., 1982. Changes in carbon uptake and allocation patterns as a result of irrigation and fertilization in a young Pinus sylvestris stand. In: Waring R.H. (Ed.) 
H. Lim et al.

Carbon Uptake and Allocation in Subalpine Ecosystems as a Key to Management, pp.

38-44. For. Res. Lab., Oregon State University, Corvallis, U.S.A.

Linder, S., Benson, M.L., Myers, B.J., Raison, R.J., 1987. Canopy dynamics and growth of

Pinus radiata.: I. Effects of irrigation and fertilization during a drought. Can. J. For. Res.

17, 1157-1165. doi: 10.1139/x87-179

Lindner, M., Maroschek, M., Netherer, S., Kremer, A., Barbati, A., Garcia-Gonzalo, J., Seidl, R., Delzon, S., Corona, P., Kolström, M., Lexer, M.J., Marchetti, M., 2010. Climate change impacts, adaptive capacity, and vulnerability of European forest ecosystems. For.

Ecol. Manage. 259, 698-709. doi: 10.1016/j.foreco.2009.09.023

Litton, C.M., Giardina, C.P., 2008. Belowground carbon flux and partitioning: global patterns and response to temperature. Funct. Ecol. 22, 941-954. doi: 10.1111/j.1365-

2435.2008.01479.x

Maier, C., Albaugh, T.J., Allen, H.L., Dougherty, P.M., 2004. Respiratory carbon use and carbon storage in mid-rotation loblolly pine (Pinus taeda L.) plantations: the effect of site resources on the stand carbon balance. Global Change Biol. 10, 1335-1350. doi:

10.1111/j.1529-8817.2003.00809.x

Mäkelä, A., Kolari, P., Karimäki, J., Nikinmaa, E., Perämäki, M., Hari, P., 2006. Modelling

five years of weather-driven variation of GPP in a boreal forest. Agric. For. Meteorol. 139, 382-398. doi: 10.1016/j.agrformet.2006.08.017

Mäkipää, R., Karjalainen, T., Pussinen, A., Kellomäki, S., 1999. Effects of climate change and nitrogen deposition on the carbon sequestration of a forest ecosystem in the boreal zone. Can. J. For. Res. 29, 1490-1501.

Mälkönen, E., Derome, J., Kukkola, M., 1990. Effects of nitrogen inputs on forest ecosystems estimation based on long-term fertilization experiments. In: Kauppi, P., Anttilla, P., Kentta mies, K., (Eds.). Acidification in Finland. Springer-Verlag. Berlin-Heidelberg, 
H. Lim et al.

pp. 325-347. doi: 10.1007/978-3-642-75450-0_17

Mälkönen, E., Kukkola, M., 1991. Effect of long-term fertilization on the biomass production and nutrient status of Scots pine stands. Fert. Res. 27, 113-127. doi:

\subsection{7/BF01048614}

McCarthy, H.R., Oren, R., Finzi, A.C., Ellsworth, D.S., Kim, H.-S., Johnsen, K.H., Millar, B., 2007. Temporal dynamics and spatial variability in the enhancement of canopy leaf area under elevated atmospheric $\mathrm{CO}_{2}$. Global Change Biol. 13, 1-19. doi: 10.1111/j.13652486.2007.01455.x

Melillo, J., Tian, H.Q., Kicklighter, D.W., McGuire, A.D., Helfrich, J., Moore, B., Vorosmarty, C.J., 1998. Effect of inter-annual climate variability on carbon storage in Amazonian ecosystems. Nature 396, 664-667. doi: 10.1038/25328

Millar, C.I., Stephenson, N.L., Stephens, S.L., 2007. Climate change and forests of the future: Managing in the face of uncertainty. Ecol. Appl. 17, 2145-2151. doi: 10.1890/06-1715.1

Monteith, J.L., 1977. Climate and the efficiency of crop production in Britain. Philos. Trans. R. Soc. London. Ser. B 281, 277-294. doi: 10.1098/rstb.1977.0140

Nikolov, N., Helmisaari, H., 1992. Silvics of the circumpolar boreal forest tree species. A systems analysis of the global boreal forest. In: Shugart, H.H., Leemans, R., GB Bonan G.B. (Eds.), A System Analysis of the Global Boreal Forest, Cambridge University Press, Cambridge, pp. 13-84.

Nilsen, P., Abrahamsen, G., 2003. Scots pine and Norway spruce stands responses to annual N, P and Mg fertilization. For. Ecol. Manage. 174, 221-232. doi: 10.1016/S0378-

\section{7(02)00024-5}

Nilson, T., 1999. Inversion of gap frequency data in forest stands. Agric. For. Meteorol. 9899, 437-448. doi: 10.1016/S0168-1923(99)00114-8

Nilsson, L.O., Wallander, H., 2003. Production of external mycelium by ectomycorrhizal 
H. Lim et al.

fungi in a Norway spruce forest was reduced in response to nitrogen fertilization. New

Phytol. 158, 409-416. doi: 10.1046/j.1469-8137.2003.00728.x

Noormets, A., Gavazzi, M.J., McNulty, S.G., Domec, J.C., Sun, G., King, J.S., Chen, j., 2010.

Response of carbon fluxes to drought in a coastal plain loblolly pine forest. Global

Change Biol. 16, 272-287. doi: 10.1111/j.1365-2486.2009.01928.x

Oishi, A.C., Palmroth, S., Johnsen, K.H., McCarthy, H., Oren, R., 2014. Sustained effects of atmospheric $\left[\mathrm{CO}_{2}\right]$ and nitrogen availability on forest soil $\mathrm{CO}_{2}$ efflux. Global Change

Biol. 20, 1146-1160. doi: 10.1111/gcb.12414

Olsson, P., Linder, S., Giesler, R., Högberg, P., 2005. Fertilization of boreal forest reduces both autotrophic and heterotrophic soil respiration. Global Change Biol. 11, 1745-1753. doi: 10.1111/j.1365-2486.2005.001033.x

Oren, R., Phillips, N., Ellsworth, D.S., Johnsen, K.H., Ewers, B.E., Maier, C., Schäfer, K.V.R., McCarthy, H., Hendrey, G., McNulty, S.G., Katul, G.G., 2001. Soil fertility limits carbon sequestration by forest ecosystems in a $\mathrm{CO}_{2}$-enriched atmosphere. Nature 411, 469-472. doi: 10.1038/35078064

Palmroth, S., Stenberg, P., Smolander, S., Voipio, P., Smolander, H., 2002. Fertilization has little effect on light-interception efficiency of Picea abies shoots. Tree Physiol. 22, 11851192.

Palmroth, S., Oren, R., McCarthy, H., Johnsen, K.H., Finzi, A.C., Butnor, J.R., Ryan, M.G., Schlesinger, W.H., 2006. Aboveground sink strength in forests controls the allocation of carbon below ground and its $\left[\mathrm{CO}_{2}\right]$-induced enhancement. Proc. Nat. Acad. Sci. USA 103, 19362-19367. doi: 10.1073/pnas.0609492103

Papaioannou, G., Papanikolaou, N., Retalis, D., 1993. Relationships of photosynthetically active radiation and shortwave irradiance. Theor. Appl. Climatol. 48, 23-27. doi: 10.1007/BF00864910 


\section{H. Lim et al.}

Peltola, H., Kilpeläinen, A., Kellomäki, S., 2002. Diameter growth of Scots pine (Pinus sylvestris) trees grown at elevated temperature and carbon dioxide concentration under boreal conditions. Tree Physiol. 22, 963-972.

Persson, H., Ahlström, K., 1990. The effects of forest liming on fertilization on fine-root growth. Water, Air, Soil Pollut. 54, 365-375.

Rautiainen, M., Stenberg, P., 2005. Application of photon recollision probability in coniferous canopy reflectance simulations. Remote Sens. Environ. 96, 98-107. doi:

10.1016/j.rse.2005.02.009

Rummukainen, M., Bergström, S., Persson, G., Rodhe, J., Tjernström, M., 2009. The Swedish Regional Climate Modelling Programme, SWECLIM: a review. Ambio 33, 176-182. doi: $10.1579 / 0044-7447-33.4 .176$

Runyon, J., Waring, R.H., Goward, S.N., Welles, J.M., 1994. Environmental limits on net primary production and light-use efficiency across the Oregon Transect. Ecol. Appl. 4, 226-237. doi: 10.2307/1941929

Ryan, M.G., 1991. A simple method for estimating gross carbon budgets for vegetation in forest ecosystems. Tree Physiol. 9, 255-266. doi: 10.1093/treephys/9.1-2.255

Sampson, D.A., Allen, H.L., 1999. Regional influences of soil available water-holding capacity and climate, and leaf area index on simulated loblolly pine productivity. For. Ecol. Manage. 124, 1-12. doi: 10.1016/S0378-1127(99)00054-7

Samuelson, L.J., Pell, C.J., Stokes, T.A., Bartkowiak, S.M., Akers, M.K., Kane, M., Markewitz, D., McGuire, M.A., Teskey, R.O., 2014. Two-year throughfall and fertilization effects on leaf physiology and growth of loblolly pine in the Georgia Piedmont. For. Ecol. Manage. 330, 29-37. doi: 10.1016/j.foreco.2014.06.030 Schoettle, A.W., Fahey, T.J., 1994. Foliage and fine root longevity of pines. Ecol. Bull. (Copenhagen). 43, 136-153. doi: 10.2307/20113137 


\section{H. Lim et al.}

Seppälä, R., Buck, A., Katila, P., 2009. Adaptation of forests and people to climate change - a global assessment report. IUFRO World Series 22.

Sigurdsson, B.D., Medhurst, J.L., Wallin, G., Eggertsson, O., Linder, S., 2013. Growth of mature boreal Norway spruce was not affected by elevated $\left[\mathrm{CO}_{2}\right]$ and/or air temperature unless nutrient availability was improved. Tree Physiol. 33, 1192-1205. doi: 10.1093/treephys/tpt043

Skomarkova, M.V., Vaganov, E.A., Mund, M., Knohl, A., Linke, P., Boerner, A., Schulze, E.D., 2006. Inter-annual and seasonal variability of radial growth, wood density and carbon isotope ratios in tree rings of beech (Fagus sylvatica) growing in Germany and Italy. Trees 20, 571-586. doi: 10.1007/s00468-006-0072-4

Spittlehouse, D.L., Stewart, R.B., 2003. Adaptation to climate change in forest management. BC J. Ecosyst. Manage. 4, 1-11.

Stenberg, P., 1996. Correcting LAI-2000 estimates for the clumping of needles in shoots of conifers. Agric. For. Meteorol. 79, 1-8. doi: 10.1016/0168-1923(95)02274-0

Stenberg, P., Palmroth, S., Bond, B.J., Sprugel, D.G., Smolander, H., 2001. Shoot structure and photosynthetic efficiency along the light gradient in a Scots pine canopy. Tree Physiol. 21, 805-814. doi: 10.1093/treephys/21.12-13.805

Strand, M., Lundmark, T., Söderbergh, I., Mellander, P.-E., 2002. Impacts of seasonal air and soil temperatures on photosynthesis in Scots pine trees. Tree Physiol. 22, 839-847. doi: 10.1093/treephys/22.12.839

Strengbom, J., Nordin, A., Näsholm, T., Ericson, L., 2001. Slow recovery of boreal forest ecosystem following decreased nitrogen input. Funct. Ecol. 15, 451-457. doi: 10.1046/j.0269-8463.2001.00538.x 
H. Lim et al.

Strengbom, J., Nordin, A., 2012. Physical disturbance determines effects from nitrogen addition on ground vegetation in boreal coniferous forest. J. Veg. Sci. 23, 361-371. doi: 10.1111/j.1654-1103.2011.01359.x

Tamm, C.O., 1991. Nitrogen in Terrestrial Ecosystems. Questions of Productivity, Vegetational Changes and Ecosystem Stability. Ecological Studies 81, Springer-Verlag, Berlin, 115 pp.

Tamm, C.O., Aronsson, A., Popovic. B., Flower-Ellis, J.G.K., 1999. Optimum nutrition and nitrogen saturation in Scots pine stands. Stud. For. Suec. 206, 126 pp.

Timmer, V.R., Morrow, L.D., 1984. Predicting fertilizer growth response and nutrient status of jack pine by foliar diagnosis. In: Stone EL (Ed.) Forest Soils and Treatment Impacts. University of Tennesse, Knoxville, TN, pp. 335-351

Valinger, E., 1993. Effects of thinning and nitrogen-fertilization on growth of Scots pine trees - total annual biomass increment, needle efficiency, and aboveground allocation of biomass increment. Can. J. For. Res. 23, 1639-1644. doi: 10.1139/x93-204

Vose, J.M., Allen, H.L., 1988. Leaf area, stemwood growth, and nutrition relationships in loblolly pine. For. Sci. 34, 547-563.

Wang, K., Kellomäki, S., Laitinen, K., 1995. Effects of needle age, long-term temperature and $\mathrm{CO}_{2}$ treatments on the photosynthesis of Scots pine. Tree Physiol. 15, 211-218. doi: 10.1093/treephys/15.4.211

Way, D.A., Oren, R., 2010. Differential responses to changes in growth temperature between trees from different functional groups and biomes: a review and synthesis of data. Tree Physiol. 30, 669-688. doi: 10.1093/treephys/tpq015

White, J., Harper, J.L., 1970. Correlated changes in plant size and number in plant populations. J. Ecol. 58, 467-485.

Whitehead, D., Jarvis, P.G., Waring, R.H., 1984. Stomatal conductance, transpiration, and 
H. Lim et al.

resistance to water uptake in a Pinus sylvestris spacing experiment. Can. J. For. Res. 14, $692-700$.

Xiao, C.W., Yuste, J.C., Janssens, I.A., Roskams, P., Nachtergale, L., Carrara, A., Sanchez, B.Y., Ceulemans, R., 2003. Above- and belowground biomass and net primary production in a 73-year-old Scots pine forest. Tree Physiol. 23, 505-516.

Yoda, K., 1963. Self-thinning in over-crowded pure stands under cultivated and natural conditions. (Intraspecific competition among higher plants. XI.). J. Biol. Osaka City Univ. 14, 107-129. 


\section{ABBREVIATIONS}

1. ANPP: aboveground NPP $\left(\mathrm{g} \mathrm{C} \mathrm{m}^{-2}\right)$

2. BA: basal area $\left(\mathrm{m}^{2}\right)$

3. $\triangle \mathrm{BA}$ : annual basal area increment $\left(\mathrm{m}^{2}\right)$

4. BNPP: belowground NPP $\left(\mathrm{g} \mathrm{C} \mathrm{m}^{-2}\right)$

5. C: carbon

6. DBH: diameter at $1.3 \mathrm{~m} \mathrm{(m)}$

7. F: fertilized stand

8. GPP: gross primary production $\left(\mathrm{g} \mathrm{C} \mathrm{m}^{-2}\right)$

9. $H$ : tree height (m)

10. $\Delta H$ : total height increment $(\mathrm{mm})$

11. I: photosynthetically active radiation $\left(\mathrm{MJ} \mathrm{m}^{-2}\right)$

12. $I_{\mathrm{C}}$ : light interception $\left(\mathrm{MJ} \mathrm{m}^{-2}\right)$

13. $L$ : leaf area index $\left(\mathrm{m}^{2} \mathrm{~m}^{-2}\right)$

14. LC: length of the green crown (m)

15. NEE: net ecosystem $C$ exchange

16. NPP: total net primary production $\left(\mathrm{g} \mathrm{C} \mathrm{m}^{-2}\right)$

17. NPP': NPP excluding fine-roots and ectomycorrhizae $\left(\mathrm{g} \mathrm{C} \mathrm{m}^{-2}\right)$

18. $\mathrm{NPP}_{\mathrm{CR}}$ : NPP of coarse-roots $\left(\mathrm{g} \mathrm{C} \mathrm{m}^{-2}\right)$

19. $\mathrm{NPP}_{\mathrm{EM}}$ : NPP of ectomycorrhizae $\left(\mathrm{g} \mathrm{C} \mathrm{m}^{-2}\right)$

20. NPP $\mathrm{FR}_{\mathrm{R}}$ NPP of fine-roots $\left(\mathrm{g} \mathrm{C} \mathrm{m}^{-2}\right)$

21. NPP : NPP of long-term carbon storing organs $\left(\mathrm{g} \mathrm{C} \mathrm{m}^{-2}\right)$

22. $P$ : growing season precipitation $(\mathrm{mm})$

23. R: reference stand

24. RC: live-crown ratio

25. RSD: relative stand density

26. SD: stand density (trees ha ${ }^{-1}$ )

27. SNA: specific (projected) needle area $\left(\mathrm{cm}^{2} \mathrm{~g}^{-1} \mathrm{dw}\right)$

28. $T$ : mean daily temperature during growing season $\left({ }^{\circ} \mathrm{C}\right)$ 


\section{Figure legends}

Fig. 1. (a) Daily mean temperature, precipitation, and (b) photosynthetically active radiation (I) during the growing season at the Svartberget field station, $8 \mathrm{~km}$ from the study site, and estimated number of days in the growing season during the study period. Mean temperature, precipitation, photosynthetically active radiation $(I)$, and length of growing season during the study period were $11.5^{\circ} \mathrm{C}, 364 \mathrm{~mm}, 1022 \mathrm{MJ} \mathrm{m}^{-2}$, and 157 days, respectively.

Fig. 2. (a) Tree ring-based relationship between basal area at $1.3 \mathrm{~m}$ in 2005 and mean of annual increment in basal area in the two growing seasons before the fertilization commenced (2004 and 2005). (b) Distribution of stem diameter at $1.3 \mathrm{~m}$ in reference and fertilized stands in 2005. (c) The size-density increases in plots of the reference and fertilized stands over the eight-year study period (arrows connecting the change from initial conditions in 2005 to the final conditions in 2013) relative to the maximum relationship obtained from 12 nearby stands undergoing self-thinning. Error bars are standard deviation $(n=3)$.

Fig. 3. Foliage nitrogen concentration (\% of dry weight) of current $(\mathrm{C}+0)$ to four-year-old $(\mathrm{C}+4)$ needles in the reference and fertilized stand in October 2011.

Fig. 4. Inter-annual dynamics of (a) leaf area index $(L)$, (b) intercepted light $\left(I_{\mathrm{C}}\right),(\mathrm{c})$ aboveground net primary production $(\mathrm{ANPP})$, and (d) NPP' $\left(\mathrm{ANPP}+\mathrm{NPP}_{\mathrm{CR}}\right)$ in the reference and fertilized stands. Error-bars indicate standard deviation ( $\mathrm{n}=11$ in (a) and (b), and 3 in (c) and $(d))$. 


\section{H. Lim et al.}

Fig. 5. (a) Relationships of aboveground net primary production (ANPP) to leaf area index $(L)$ in the reference and fertilized stands. (b) Relationships of NPP' $\left(\mathrm{ANPP}+\mathrm{NPP}_{\mathrm{CR}}\right)$ to $L$ in both stands. Error-bars indicate standard deviation $(\mathrm{n}=3)$. For fitting parameters see Table 1.

Fig. 6. Relationships of net primary production, excluding fine-roots and ectomycorrhizae (NPP') and NPPs of woody components (stem wood, branches, coarse-roots, and cones) to climate variables in the reference and fertilized stands. In (a) and (b), the relationships are with growing season daily mean temperature; and in (c) and (d), the residuals from the linear regressions with the temperature are related to growing season precipitation. Error-bars indicate standard deviation $(\mathrm{n}=3)$. For fitting parameters and statistics see Table 1 .

Fig. 7. Frequency of mean growing season temperature (a) and precipitation (b) over a 33year record from the Svartberget field station $8 \mathrm{~km}$ from the study site. (c) Relationships between the increase of net primary production of woody biomass components $\left(\mathrm{NPP}_{\mathrm{S}}\right)$ with $\mathrm{N}$-fertilization relative to the reference stand versus growing season precipitation observed over a 33-year record, with temperature set to the mean and extremes of growing season temperature of the same record. The vertical dash line is average precipitation over a 33-year record; the white zone is the range of observed precipitation during the study period (2006 2013); the grey zone represents the long-term record. 
H. Lim et al.

\section{Table legends}

Table 1. Coefficient of determinants and parameters of the equations $(y=a x+b)$ in Fig. 5 and 6.

Table 2. Intercepted light during the growing season $\left(I_{\mathrm{C}}\right)$, carbon partitioning $\left(\mathrm{g} \mathrm{C} \mathrm{m}^{-2} \mathrm{yr}^{-1}\right)$, and the relative contribution to NPP of different components in reference (R) and fertilized (F) stands in 2012. 
Table 1. Coefficient of determinants and parameters of the equations $(y=a x+b)$ in Fig. 5 and 6 .

\begin{tabular}{|c|c|c|c|c|c|c|c|c|c|}
\hline \multirow{2}{*}{ Figure } & \multirow{2}{*}{$y$} & \multirow{2}{*}{$x$} & \multirow{2}{*}{ Stand } & \multirow{2}{*}{$a$} & \multirow{2}{*}{$b$} & \multirow{2}{*}{$r^{2}$} & \multirow{2}{*}{ P-value } & \multicolumn{2}{|c|}{ P-value of ANCOVA test } \\
\hline & & & & & & & & Slope & Intercept \\
\hline \multirow[t]{2}{*}{$5 \mathrm{a}$} & $\operatorname{ANPP}\left(\mathrm{g} \mathrm{C} \mathrm{m}^{-2}\right)$ & Leaf area index & $\mathrm{R}$ & 163.9 & -126.4 & 0.38 & 0.001 & 0.821 & $<0.001$ \\
\hline & & & $\mathrm{F}$ & 163.9 & -63.3 & 0.55 & $<0.001$ & & \\
\hline \multirow[t]{2}{*}{$5 b$} & $\mathrm{NPP}\left(\mathrm{g} \mathrm{C} \mathrm{m}^{-2}\right)$ & & $\mathrm{R}$ & 174.9 & -125.3 & 0.32 & 0.004 & 0.998 & $<0.001$ \\
\hline & & & $\mathrm{F}$ & 174.9 & -51.1 & 0.49 & $<0.001$ & & \\
\hline \multirow[t]{2}{*}{$6 a$} & NPP' $\left(\mathrm{g} \mathrm{C} \mathrm{m}^{-2}\right)$ & Temperature $\left({ }^{\circ} \mathrm{C}\right)$ & $\mathrm{R}$ & 41.7 & -211.1 & 0.58 & $<0.001$ & 0.741 & $<0.001$ \\
\hline & & & $\mathrm{F}$ & 41.7 & -103.0 & 0.31 & 0.004 & & \\
\hline \multirow[t]{2}{*}{$6 b$} & $\mathrm{NPP}_{\mathrm{S}}\left(\mathrm{g} \mathrm{C} \mathrm{m}^{-2}\right)$ & & $\mathrm{R}$ & 25.6 & -107.4 & 0.35 & 0.003 & 0.834 & $<0.001$ \\
\hline & & & $\mathrm{F}$ & 25.6 & -37.2 & 0.21 & 0.023 & & \\
\hline \multirow[t]{2}{*}{$6 c$} & Residuals with NPP' & Precipitation (mm) & $\mathrm{R}$ & & & & 0.149 & & \\
\hline & & & $\mathrm{F}$ & 1.5 & -564.1 & 0.76 & $<0.001$ & & \\
\hline \multirow[t]{2}{*}{$6 \mathrm{~d}$} & Residuals with $\mathrm{NPP}_{\mathrm{S}}$ & & $\mathrm{R}$ & & & & 0.738 & & \\
\hline & & & $\mathrm{F}$ & 1.0 & -355.9 & 0.48 & $<0.001$ & & \\
\hline
\end{tabular}

$L$ : leaf area index; ANPP: net primary production aboveground; NPP': net primary production (NPP) excluding fine-roots and ectomycorrhizae; NPP ${ }_{S}$ sum of NPP in stem wood, branches, coarse-roots, and cones; R: reference stand; F: fertilized stand. 
Table 2. Intercepted light during the growing season $\left(I_{\mathrm{C}}\right)$, carbon partitioning $\left(\mathrm{g} \mathrm{C} \mathrm{m}^{-2} \mathrm{yr}^{-1}\right)$, and the relative contribution to NPP of different components in reference (R) and fertilized (F) stands in 2012.

\begin{tabular}{lllllrr}
\hline Components & $\mathrm{R}$ & \% NPP & $\mathrm{F}$ & \% NPP & $F / R$ & P-value \\
\hline$I_{\mathrm{C}}\left(\mathrm{MJ} \mathrm{m}^{-2}\right)$ & $642(83)$ & & $713(121)$ & & 1.11 & 0.489 \\
\hline ANPP $\left(\mathrm{g} \mathrm{C} \mathrm{m}^{-2} \mathrm{yr}^{-1}\right)$ & $262(29)$ & 0.50 & $340(23)$ & 0.67 & 1.30 & $\mathbf{0 . 0 2 4}$ \\
Stem & $114(13)$ & 0.22 & $156(10)$ & 0.31 & 1.37 & $\mathbf{0 . 0 1 2}$ \\
Branch & $39(25)$ & 0.08 & $47(20)$ & 0.09 & 1.20 & 0.691 \\
Foliage & $99(22)$ & 0.19 & $118(39)$ & 0.23 & 1.19 & 0.195 \\
Cone & $5.2(0.02)$ & 0.01 & $9.0(0.08)$ & 0.02 & 1.72 & $<\mathbf{0 . 0 0 1}$ \\
Miscellaneous from litterfall & $4.9(0.02)$ & 0.01 & $9.4(0.08)$ & 0.02 & 1.92 & 0.186 \\
$\mathrm{BNPP}\left(\mathrm{g} \mathrm{C} \mathrm{m}^{-2} \mathrm{yr}^{-1}\right)$ & $257(9)$ & 0.50 & $165(8)$ & 0.33 & 0.64 & $\mathbf{0 . 0 0 6}$ \\
NPP & $21(3)$ & 0.04 & $34(2)$ & 0.07 & 1.57 & $\mathbf{0 . 0 0 4}$ \\
$\mathrm{NPP}_{\mathrm{FR}}$ & $138(6)$ & 0.27 & $92(7)$ & 0.18 & 0.67 & $\mathbf{0 . 0 0 5}$ \\
${ }^{\mathrm{a}} \mathrm{NPP}_{\mathrm{EM}}$ & $98(5)$ & 0.19 & $40(3)$ & 0.08 & 0.41 & $\mathbf{0 . 0 0 3}$ \\
$\mathrm{NPP}\left(\mathrm{g} \mathrm{C} \mathrm{m}^{-2} \mathrm{yr}^{-1}\right)$ & $519(30)$ & 1.00 & $505(24)$ & 1.00 & 0.97 & 0.603 \\
\hline
\end{tabular}

ANPP: net primary production (NPP) aboveground; BNPP: NPP belowground; $\mathrm{NPP}_{\mathrm{CR}}$ : NPP of coarse-roots; $\mathrm{NPP}_{\mathrm{FR}}$ : NPP of fine-roots; NPP $\mathrm{EM}_{\mathrm{NPP}}$ of ectomycorrhizae.

${ }^{a} \mathrm{NPP}_{\mathrm{EM}}$ was estimated by $\mathrm{NPP}_{\mathrm{FR}}$ multiplying the ratio of ectomycorrhiza-respiration to root-respiration measured in the experiment site $(0.43$ in $\mathrm{F}$ and 0.71 in

R; Hasselquist et al., 2012). 


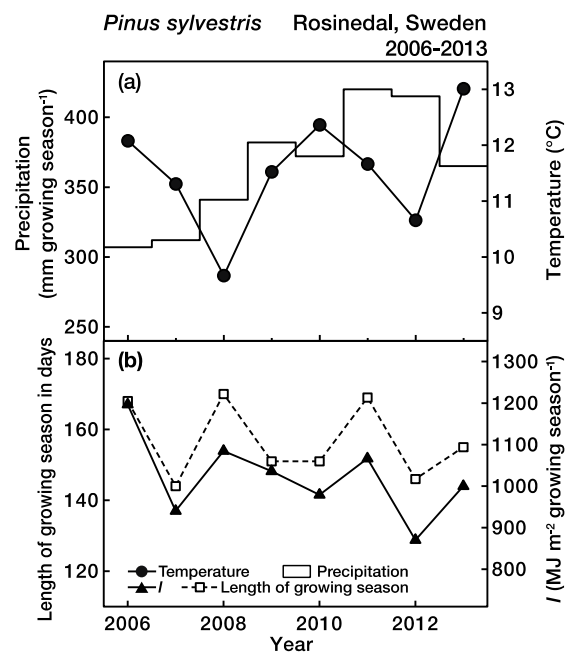

Fig. 1. (a) Daily mean temperature, precipitation, and (b) photosynthetically active radiation $(I)$ during the growing season at the Svartberget field station, $8 \mathrm{~km}$ from the study site, and estimated number of days in the growing season during the study period. Mean temperature, precipitation, photosynthetically active radiation $(I)$, and length of growing season during the study period were $11.5^{\circ} \mathrm{C}, 364 \mathrm{~mm}, 1022 \mathrm{MJ} \mathrm{m}^{-}$ ${ }^{2}$, and 157 days, respectively. 

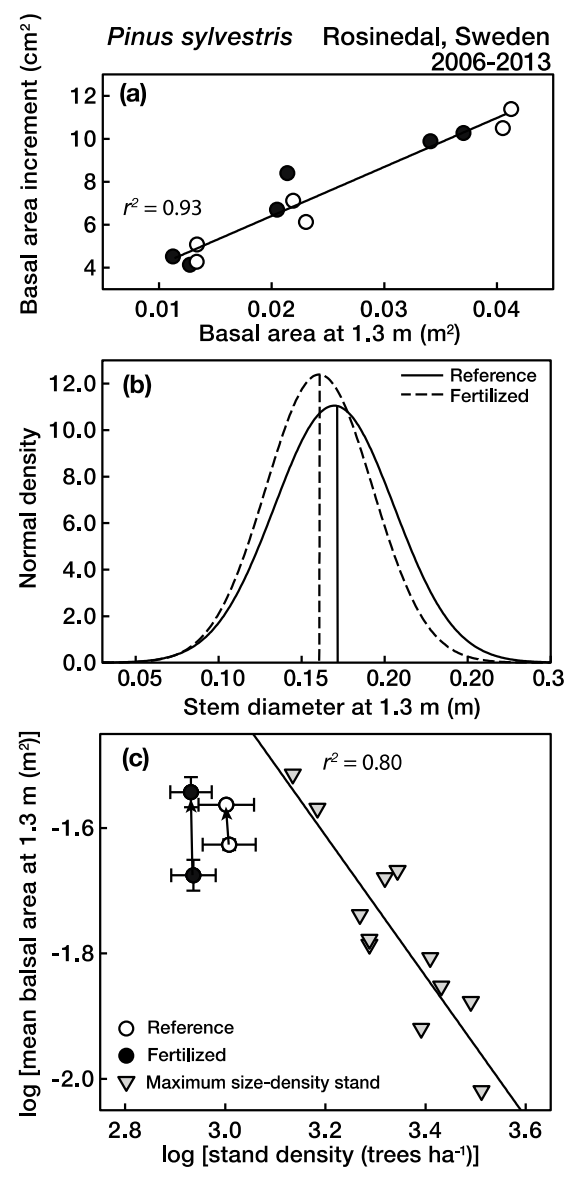

Fig. 2. (a) Tree ring-based relationship between basal area at $1.3 \mathrm{~m}$ in 2005 and mean of annual increment in basal area in the two growing seasons before the fertilization commenced (2004 and 2005). (b) Distribution of stem diameter at $1.3 \mathrm{~m}$ in reference and fertilized stands in 2005. (c) The size-density increases in plots of the reference and fertilized stands over the eight-year study period (arrows connecting the change from initial conditions in 2005 to the final conditions in 2013) relative to the maximum relationship obtained from 12 nearby stands undergoing self-thinning. Error bars are standard deviation $(\mathrm{n}=3)$. 


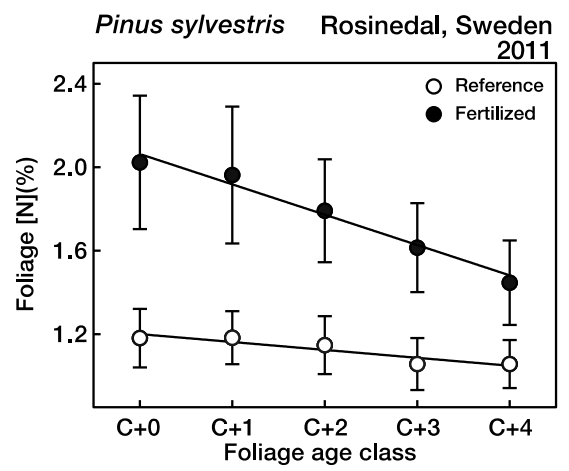

Fig. 3. Foliage nitrogen concentration (\% of dry weight) of current $(\mathrm{C}+0)$ to four-year old needles $(\mathrm{C}+4)$ in the reference and fertilized stands in October 2011. 


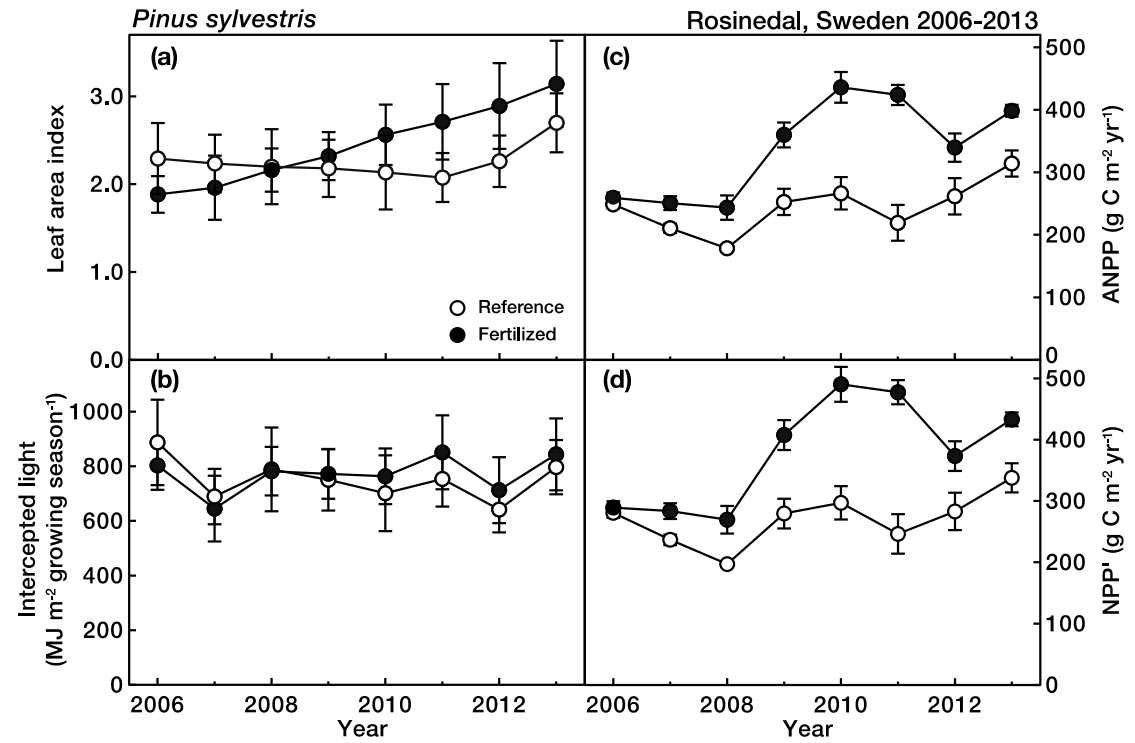

Fig. 4. Inter-annual dynamics of (a) leaf area index $(L)$, (b) intercepted light $\left(I_{\mathrm{C}}\right)$, (c) aboveground net primary production $(\mathrm{ANPP})$, and (d) NPP' $\left(\mathrm{ANPP}+\mathrm{NPP}_{\mathrm{CR}}\right)$ in the reference and fertilized stands. Error-bars indicate standard deviation ( $\mathrm{n}=11$ in (a) and (b), and 3 in (c) and (d)). 


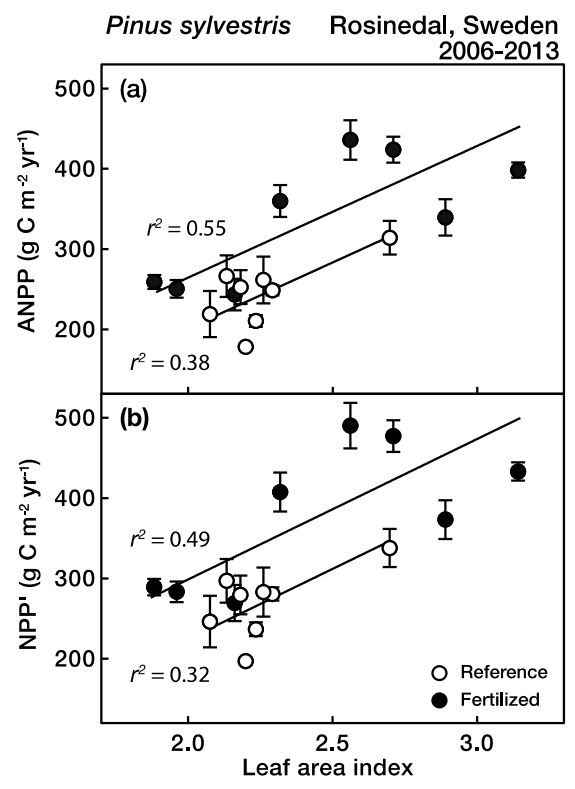

Fig. 5. (a) Relationships of aboveground net primary production (ANPP) to leaf area index $(L)$ in the reference and fertilized stands. (b) Relationships of NPP'(ANPP + $\left.\mathrm{NPP}_{\mathrm{CR}}\right)$ to $L$ in both stands. Error-bars indicate standard deviation $(\mathrm{n}=3)$. For fitting parameters see Table 1 . 


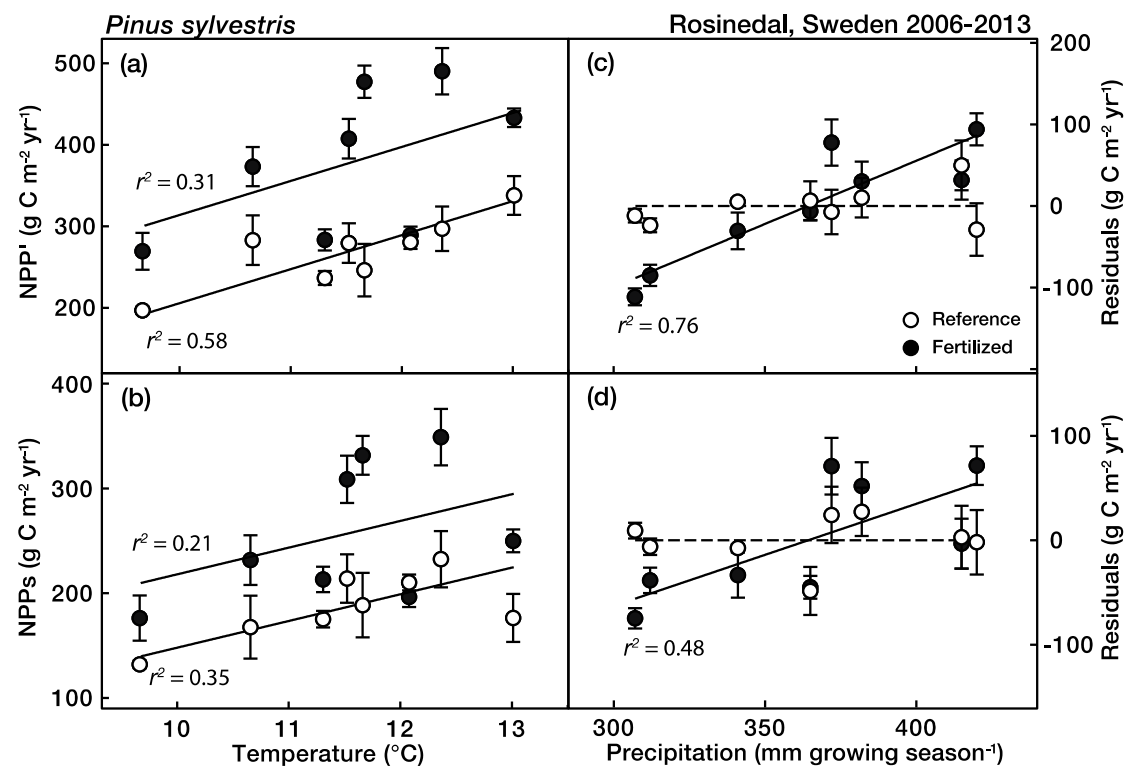

Fig. 6. Relationships of net primary production, excluding fine-roots and ectomycorrhizae (NPP') and NPPs of woody components (stem wood, branches, coarse-roots, and cones) to climate variables in the reference and fertilized stands. In (a) and (b), the relationships are with growing season mean daily temperature; and in (c) and (d), the residuals from the linear regressions with the temperature are related to growing season precipitation. Error-bars indicate standard deviation $(n=3)$. For fitting parameters and statistics see Table 1. 


\section{APPENDIX}

\section{Destructive harvests}

Destructive tree sampling was performed twice to capture the pre-treatment period and the time likely corresponding with a stable treatment response. The first sampling was in early June 2006, thus representing biomass following the pretreatment 2005 growing season. Five trees were selected in each stand to cover the range of tree diameters in the three stands. The trees were cut close to the ground and, after felling, tree height $(H)$ and length of the green crown (LC; $1 \mathrm{~cm}$ accuracy), and stem diameter at $1 \mathrm{~m}$ intervals from the bottom of the stem, as well as at $1.3 \mathrm{~m}$ aboveground (DBH; $1 \mathrm{~mm}$ accuracy) were measured. The green crown was divided into four equal length strata. Branch samples were selected by dividing stem cross section into four quadrants, and one representative branch was reserved from each quadrant in each of the four strata. The sample branch was weighed as a whole and then separated into components: branches (wood and bark), foliage, cones, and dead twigs; the fresh weight of each was obtained ( $0.5 \mathrm{~g}$ accuracy). The remaining branches of each stratum were then cut and weighed in bulk.

Stem discs were taken at ground level, $1.3 \mathrm{~m}$, and $30,55,70$, and $85 \%$ of the total stem length. Dead branches below the crown base were separated from the stem. The six stem discs and the logs in between, and dead branches were separately weighed in the field ( $0.5 \mathrm{~g}$ accuracy). The long and short diameters of each disc and bark thickness were measured using a ruler ( $1 \mathrm{~mm}$ accuracy) and bark was separated from the discs. All samples were oven-dried at $65^{\circ} \mathrm{C}$ to constant weight (this applies to all dry weights hereafter).

In October 2011, following six years of fertilization, six trees were harvested in each of the $\mathrm{R}$ and $\mathrm{F}$ stands representing the range of tree diameter in the stands. The 
stumps of cut trees were marked for later extraction for coarse-root biomass determination. The $H, \mathrm{LC}$, and stem diameter in every meter from the bottom of the stem were measured. Height increments $(\Delta H)$ were measured for each of the recent 10 years, based on branch whorls (1 $\mathrm{cm}$ accuracy).

The green crown was divided into five equal strata. Two representative branches from each of two opposite crown quadrants were taken from each stratum for further processing; two branches were taken from the first and third quadrants in the first stratum beginning at the crown base, from the second and forth quadrants in the second stratum, etc. The fresh weight of the rest of the branches in each stratum was obtained in the field in bulk.

In the laboratory, the shoots of each sample branch were separated by age class and the foliage was removed from the twigs. Foliage in each age class, shoots and branches (including wood and bark), cones, and dead twigs were dried and separately weighed. Twenty fresh fascicles from each age class in each stratum of each tree were scanned using a flatbed scanner (Epson $1600^{+}$equipped for dual scanning) and the scans analyzed for projected foliage area using WinSEEDLE Pro 5.1a analysis software (Regent instruments Inc., Canada). The sample fascicles were dried and weighed (0.1 mg accuracy). Specific (projected) needle area (SNA) was calculated by dividing scanned foliage area for each sample by its dry weight.

The dry material from each sample of each component in each crown stratum was summed and expressed as a proportion of the fresh branch weight. Multiplying this ratio by the fresh weight of all branches in a stratum gave an estimate of the component dry weight. These values were used to derive the vertical distribution of needle mass by age class, branch, and cone mass, within the crown and combined 
with [N], [C], and SNA, distributions and total amounts of $\mathrm{N}$ and $\mathrm{C}$, and leaf area were estimated.

Stem discs were collected from each tree at ground level, $1.3 \mathrm{~m}$, and 30 and 55\% of the total stem length, as well as at crown base, and 20, 40, 60 and $80 \%$ of the LC. Stem discs, logs in between, and dead twigs below the crown base were weighed in the field. The surfaces of the discs at $1.3 \mathrm{~m}$ height and the crown base were sanded and scanned, and tree-ring widths $(0.01 \mathrm{~mm}$ accuracy) were measured on four perpendicular radii from the pith using WinDENDRO (Regent Instruments Inc., QC, Canada). The discs were stained with a heartwood reagent (sulfanilic acid saturated with sodium nitrite, Cummings, 1972) and sapwood area was calculated by the difference between the total disc area under bark and the heartwood area based on the four radii.

To calculate basic wood density, six stem cores were taken in each stand in July 2013 using a $1.2 \mathrm{~cm}$ inside diameter increment borer. To avoid shrinking by drying, the cores were immediately put in a cooler, transported to the laboratory, and processed. The cores were separated into two periods: 2012 - 2008 and 2005 - 1996, and the wood density of each period was calculated using the section volume, i.e. length multiplied by inner cross-sectional area of the borer $\left(1.131 \mathrm{~cm}^{2}\right)$, and its dry weight (1 mg accuracy). The dried cores were also analyzed for $[\mathrm{N}]$ and $[\mathrm{C}]$.

Coarse-root (diameter $>2 \mathrm{~mm}$ ) biomass in the stands was estimated combining two approaches: 1) extracting the tree-stump and coarse-roots of the harvested trees, and 2) sampling coarse-roots between trees. Tap- and coarse-roots of harvested trees were extracted from a $2 \mathrm{~m}$ diameter circular excavation centered on the pith of each tree stump to a depth of $1 \mathrm{~m}\left(3.14 \mathrm{~m}^{3}\right)$. After removing soil from the roots, they were weighed in bulk to $10 \mathrm{~g}$ accuracy. Roots were then divided into four quadrants from 
the pith, and one quadrant of each tree was weighed fresh, and again after ovendrying. Roots between trees were collected from three trenches (10 $\mathrm{m}$ in length, and $0.7 \mathrm{~m}$ in width and depth, or $4.9 \mathrm{~m}^{3}$ ) in each stand positioned between trees of DBH representing the range of tree diameters in the stand. The distance between trees and trenches ranged 1 to $3 \mathrm{~m}$. Collected roots were rinsed in water to remove soil from the surface, oven-dried and weighed.

Coarse-root mass was estimated from the coarse-root dry-to-fresh mass ratio near trees and between trees multiplied by the total fresh weight of roots of the respective position. The estimates near and between trees were scaled to the stand based on the fraction of area represented by each condition.

For the fine-root biomass measurements, ten soil cores were randomly taken from the $\mathrm{F}$ and $\mathrm{R}$ stands with a soil corer (39 $\mathrm{mm}$ in diameter) in the beginning of June 2013. The cores were divided into sections comprising the organic layer (2 - 5 $\mathrm{cm})$ and the $0-5,5-10,10-15$, and $15-20 \mathrm{~cm}$ mineral soil layers, which was considered to be an adequate sampling depth for $P$. sylvestris stands according to Helmisaari et al. (2007). Roots were separated from the soil by washing as described in Leppälammi-Kujansuu et al. (2014a) and sorted under a dissecting microscope into dead and living and further to $P$. sylvestris and understory roots, in two diameter classes $(<1 \mathrm{~mm}$ and $1-2 \mathrm{~mm})$. Roots were then dried and weighed. No stoniness correction was made for the biomass because the soil was fine sand without stones.

\section{Data analysis}

\section{Estimating standing biomass components}

To estimate standing biomass of the stands, we developed allometric equations based on $\mathrm{DBH}, H$, and LC using least square regression analysis (see supplementary 
Table S1). Briefly, we first processed the data from trees harvested in 2006 and 2011, then employed the allometric relationships and fractions with the mensuration data to estimate annual production of different biomass components.

Stem and bark volume of the harvested trees was calculated using Smailian's formula (Avery and Burkhart, 1983); average cross-sectional area of the two $1 \mathrm{~m} \mathrm{log}$ ends were multiplied by the length $(1 \mathrm{~m})$; the volume of the top log was calculated as a cone. Summing up log volumes gave stem volume. Wood volume was estimated using the same approach with diameter under bark, and the bark volume by difference (stem volume - wood volume). Dry mass of stem and bark was estimated from dryto-fresh mass ratio obtained from the discs, multiplied by total fresh mass of the stem logs plus discs.

Estimating annual biomass production of stem from annual mensuration measurements and allometric-based volume of stem wood and bark requires annual estimates of wood density (assuming bark density changes as much as wood density changes over time). Our harvests provided us with estimates of wood density of the stem before the treatment (up to 2006 harvest), but in the later harvest (2011), the effect of fertilization, as well as of stand development, may be masked by wood mostly produced before 2006. From the cores taken at $1.3 \mathrm{~m}$ height in 2013 , we estimated wood density for the period just before fertilization and over the fertilization period. The wood density from the 2011 cores for the period of 1996 to $2005\left(0.45 \pm 0.07 \mathrm{~g} \mathrm{~cm}^{-3}\right.$, similar in $\mathrm{R}$ and $\mathrm{F}$ stands, $\left.\mathrm{P}=0.600\right)$ was close to the estimate of whole stem wood density obtained from the 2006 harvest $(0.47 \pm 0.02 \mathrm{~g}$ $\mathrm{cm}^{-3}$, again similar in $\mathrm{R}$ and $\mathrm{F}$ stands, $\left.\mathrm{P}=0.970\right)$. Thus, we used the cores to estimate whole-stem wood density over the period 2006 - 2012, during which wood density was higher in $\mathrm{R}$ than in $\mathrm{F}(0.47 \pm 0.06$ and $0.42 \pm 0.03$, respectively; $\mathrm{P}=0.032)$. 
The length of the green crown, in addition to diameter and height, can be used to improve estimates of foliage biomass and branch biomass replacement. We estimated LC of the trees from a relationship developed based on the 20 trees with LC and $H$ measurements in each plot. We first normalized LC by $H$ (live-crown ratio, RC), and estimated simple averages of $\mathrm{RC}$ for each plot in $\mathrm{R}$ and $\mathrm{F}$ for each year. Variations of $\mathrm{RC}$ from the mean in both $\mathrm{R}$ and $\mathrm{F}$ were related to $\mathrm{DBH}$, and the relationships were similar at both stands $(\mathrm{P}=0.155)$. Thus, we computed an adjustment factor $(1.586 \times$ $\left.\mathrm{DBH}+0.708, r^{2}=0.15, \mathrm{P}<0.001\right)$, adjusting the mean treatment $\mathrm{RC}$ to individual tree RC based on its DBH.

Three sets of allometric coefficients were determined (see Table S1). Trees harvested in 2006 from all three stands (including the $\mathrm{N}$-deposition stand, $\mathrm{n}=15$ ), and trees harvested in 2011 in $R$ and F separately ( $n=6$ in each). Trees were combined in 2006 after finding that the relationships were not different among the three stands $(\mathrm{P}$ $=0.418$ ). Relationships for estimating cone biomass did not change within a stand between 2006 and 2011 (minimum $\mathrm{P}=0.414$ ), but were different between the stands $(\mathrm{P}<0.001)$, obviously not due to the treatment. Therefore, one allometric relationship for cones was developed for each stand for the study period $(n=11$ trees). Allometric functions for stem wood and bark volume, and branch and coarse-root mass were derived using all harvested trees after finding no difference among the relationships (n $=27$, minimum $\mathrm{P}=0.264$ ). Only foliage biomass required separate functions for the period prior to the initiation of the study, and later between the treatments.

In the 2006-harvest, root biomass was not estimated and foliage was not separated into age classes. Given the age of the forest, we assumed that it is in steady state with respect to these quantities and that the estimates from $\mathrm{R}$ in 2011 are representative of all three stands in 2006. 


\section{Net primary production}

Stem wood NPP was calculated by annual difference of stem wood volume multiplied the specific wood gravity and [C]. Bark NPP was calculated likewise but with the addition of bark mass in litter fall. NPP of roots was calculated by annual difference of biomass multiplied by [C] of wood. Foliage NPP was estimated by summing annual litter fall and annual increment of leaf biomass, estimated from the increment of $L$ (described below) divided by SNA and multiplied by [C] in each of foliage age class. Branch NPP was calculated as the sum of annual difference of branch biomass and the estimate of branch replacement, determined based on the rate of upward movement of the crown and the branch biomass per meter of crown in the lowest stratum. The NPP of cones was calculated by difference of cone mass with the addition of that in litter fall. The NPP of fine-roots for $2012(<2 \mathrm{~mm})$ was estimated as fine-root biomass, 0.5 turnover rate (Hansson et al., 2013; Leppälammi-Kujansuu et al., 2014b), and 52.6 and $55.4 \%$ of [C] for $1-2 \mathrm{~mm}$ and $<1 \mathrm{~mm}$, respectively (Janssens et al., 1999).

\section{Specific needle area, leaf area index, and canopy foliage [N]}

The SNA of current foliage was significantly higher than from other age classes when testing for the entire crown (one-way ANOVA, Tukey's test, $\mathrm{n}=30, \mathrm{P}<0.0001$ in both stands) as well as within each crown stratum (ANOVA, Tukey's test, $\mathrm{n}=6$, maximum $\mathrm{P}=0.003$ ). In none of the strata did SNA differ among the older age classes (minimum $\mathrm{P}=0.540$ ). The $\mathrm{SNA}$ progressively increased from the top of the crown downward in all age classes $(n=6$, maximum $P=0.002)$. Thus, two values of SNA were used in each layer in each stand, one for current needles and another for older age classes. 
Leaf area index estimated by combining foliage mass and SNA of harvested trees, and scaling to the stand provided a fairly accurate estimate at the two times corresponding to the harvests. However, scaling individual tree foliage mass to stand $L$ over time does not account for climate-induced dynamics in the foliage mass-DBH $\times$ LC relationship. Using a single relationship tends to result in monotonically increasing stand-scale biomass as long as tree diameter increases and there is little or no mortality. Thus, we estimated $L$ combining three types of data: (1) allometry-based foliage mass for the harvest years of 2006 and 2011, and SNA of 2011, (2) hemispherical photographs, and (3) litter fall to generate seasonal dynamics of production and loss. Minimum $L$ was generated using hemispherical photographs taken before bud break. This indirect method for estimating 'effective' $L$ underestimates the 'true' $L$ because of overlap among canopy elements. We adjusted the effective $L$ estimates upward to projected $L$ using a correction factor $(1.45 \pm 0.16)$ that was based on concurrent direct and indirect $L$ measurements in 2006 and 2011 . The intra-annual variation of $L$ was based on published high frequency litter fall records (Flower-Ellis and Persson, 1980), adjusted by the biannual litter fall collection. Leaf area production estimates, i.e. the annual difference of $L$, were converted to needle biomass divided by SNA in each age class estimated based on needle retention rate from the 2011 harvest.

Foliage $[\mathrm{N}]$ at the canopy scale was calculated by the proportion of foliage-mass multiplied by $[\mathrm{N}]$ in each of five age class and crown strata and then summed up for each of the six 2011 sample trees in each stand (see Table S2 and S3).

Canopy light interception $\left(I_{\mathrm{C}}\right)$ was calculated using Beer-Lambert's Law:

$$
\begin{aligned}
& I=I_{O} e^{-k L} \\
& I_{C}=I_{O}\left(1-e^{-k L}\right),
\end{aligned}
$$


where $I$ and $I_{O}$ are the amounts of radiation received on horizontal surface at a given height and at the top of the canopy, $k$ is the light extinction coefficient and $L$ is the leaf area index above the observation height. We determined $k$ by simulating canopy radiative transfer using a one-dimensional, multi-layer model (Kim et al., 2011), where calculation of $I$ at each canopy layer is based on vertical profiles of surface area of needles, stems and branches, needle angle distribution, and clumping of foliage to shoots and crowns. We described the canopy structure using tree- and stand-level data and allometric relationships from the present study, or on literature for unavailable data (branch surface area and its vertical profile, Halldin, 1985; Ilvesniemi and Liu, 2001; Rautiainen and Stenberg, 2005). Using measured daily integrals of $I_{O}$ and simulated $I$ and in 2011, we solved the $k$ in Eq. (2) for each day of the growing season. The daily values of $k$ were averaged to obtain an estimate of 'effective canopy $k^{\prime}$, which was used in calculating $I_{\mathrm{C}}$ (Eq. (3)) of the R and F stands for $2006-2013$. 


\section{Tables in Appendix}

Table A1. Stand characteristics in the reference (R) and fertilized (F) stands in the year before fertilization commenced (2005) and at the end of the present study period (2013).

Table A2. Net primary production $\left(\mathrm{g} \mathrm{C} \mathrm{m}^{-2} \mathrm{yr}^{-1}\right)$ of woody components (NPP') in the reference (R) and fertilized stands (F).

Table A3. Mean nutrient concentration $\left(\mathrm{mg} \mathrm{g}^{-1}\right)$ of macronutrients and boron in one-year-old foliage in the reference (R) and fertilized (F) stands two years after the treatment commenced. 
Table A1. Stand characteristics in the reference (R) and fertilized (F) stands in the year before fertilization commenced (2005) and at the end of the present study period (2013).

\begin{tabular}{|c|c|c|c|c|c|c|c|c|}
\hline \multirow{3}{*}{ Year } & \multirow{2}{*}{\multicolumn{2}{|c|}{ Stand density $\left(\right.$ tree $\left.\mathrm{ha}^{-1}\right)$}} & \multirow{2}{*}{\multicolumn{2}{|c|}{$\begin{array}{l}\text { Quadratic mean diameter } \\
\text { at } 1.3 \mathrm{~m}(\mathrm{~cm})\end{array}$}} & \multirow{2}{*}{\multicolumn{2}{|c|}{ Mean tree height $(\mathrm{m})$}} & \multirow{2}{*}{\multicolumn{2}{|c|}{ Stem volume $\left(\mathrm{m}^{3} \mathrm{ha}^{-1}\right)$}} \\
\hline & & & & & & & & \\
\hline & $\mathrm{R}$ & $\mathrm{F}$ & $\mathrm{R}$ & $\mathrm{F}$ & $\mathrm{R}$ & $\mathrm{F}$ & $\mathrm{R}$ & $\mathrm{F}$ \\
\hline 2005 & $1023(122)$ & $867(91)$ & $17.3(0.2)$ & $16.4(0.5)$ & $15.9(0.0)$ & $14.1(0.2)$ & $196(24)$ & $136 \quad(9)$ \\
\hline 2013 & $1010(125)$ & $857(83)$ & $18.6(0.1)$ & $19.1(0.5)$ & $17.5(0.0)$ & $16.6(0.2)$ & $237(28)$ & $201(14)$ \\
\hline
\end{tabular}

Values within parenthesis are standard deviations. 
Table A2. Net primary production $\left(\mathrm{g} \mathrm{C} \mathrm{m}^{-2} \mathrm{yr}^{-1}\right)$ of woody components (NPP') in the reference (R) and fertilized stands (N).

\begin{tabular}{|c|c|c|c|c|c|c|c|c|c|c|}
\hline \multirow[t]{2}{*}{ NPP of components } & \multicolumn{2}{|l|}{ Stem } & \multicolumn{2}{|c|}{ Branches } & \multicolumn{2}{|c|}{ Coarse-roots } & \multicolumn{2}{|c|}{ Foliage } & \multicolumn{2}{|c|}{ Cones } \\
\hline & $\mathrm{R}$ & $\mathrm{F}$ & $\mathrm{R}$ & $\mathrm{F}$ & $\mathrm{R}$ & $\mathrm{F}$ & $\mathrm{R}$ & $\mathrm{F}$ & $\mathrm{R}$ & $\mathrm{F}$ \\
\hline 2006 & $\begin{array}{l}155.5 \\
(10.5)\end{array}$ & $\begin{array}{l}144.7 \\
(8.1)\end{array}$ & $\begin{array}{l}31.4 \\
(6.4)\end{array}$ & $\begin{array}{l}28.8 \\
(0.5)\end{array}$ & $\begin{array}{l}32.0 \\
(2.4)\end{array}$ & $\begin{array}{l}30.1 \\
(1.7)\end{array}$ & $\begin{array}{l}49.9 \\
(15.1)\end{array}$ & $\begin{array}{l}71.4 * * \\
(15.8)\end{array}$ & $\begin{array}{l}6.9 \\
(0.0)\end{array}$ & $\begin{array}{l}10.3^{* * *} \\
(0.1)\end{array}$ \\
\hline 2007 & $\begin{array}{l}130.8 \\
(10.5)\end{array}$ & $\begin{array}{l}156.3^{*} \\
(8.1)\end{array}$ & $\begin{array}{l}27.3 \\
(6.4)\end{array}$ & $\begin{array}{l}32.4 \\
(0.5)\end{array}$ & $\begin{array}{l}26.2 \\
(2.4)\end{array}$ & $\begin{array}{l}32.8^{*} \\
(1.7)\end{array}$ & $\begin{array}{l}42.7 \\
(9.9)\end{array}$ & $\begin{array}{l}49.2 \\
(15.8)\end{array}$ & $\begin{array}{l}5.3 \\
(0.0)\end{array}$ & $\begin{array}{l}8.9 * * \\
(0.1)\end{array}$ \\
\hline 2008 & $\begin{array}{l}100.3 \\
(10.4)\end{array}$ & $\begin{array}{l}125.9 \\
(14.4)\end{array}$ & $\begin{array}{l}20.8 \\
(8.7)\end{array}$ & $\begin{array}{l}20.0 \\
(7.6)\end{array}$ & $\begin{array}{l}18.7 \\
(2.2)\end{array}$ & $\begin{array}{l}26.0 * \\
(3.1)\end{array}$ & $\begin{array}{l}42.0 \\
(11.9)\end{array}$ & $\begin{array}{l}67.1 * * \\
(13.0)\end{array}$ & $\begin{array}{l}7.6 \\
(0.0)\end{array}$ & $\begin{array}{l}20.7 * * \\
(0.1)\end{array}$ \\
\hline 2009 & $\begin{array}{l}136.8 \\
(15.5)\end{array}$ & $\begin{array}{l}222.6^{* * *} \\
(19.4)\end{array}$ & $\begin{array}{l}55.1 \\
(5.6)\end{array}$ & $\begin{array}{l}46.4 \\
(0.7)\end{array}$ & $\begin{array}{l}26.8 \\
(3.1)\end{array}$ & $\begin{array}{l}47.7 * * \\
(4.5)\end{array}$ & $\begin{array}{l}47.3 \\
(13.5)\end{array}$ & $\begin{array}{l}69.4 * * \\
(15.3)\end{array}$ & $\begin{array}{l}9.3 \\
(0.0)\end{array}$ & $\begin{array}{l}14.5^{* * *} \\
(0.1)\end{array}$ \\
\hline 2010 & $\begin{array}{l}160.7 \\
(7.5)\end{array}$ & $\begin{array}{l}253.4 * * \\
(17.9)\end{array}$ & $\begin{array}{l}54.3 \\
(20.6)\end{array}$ & $\begin{array}{l}59.5 \\
(7.4)\end{array}$ & $\begin{array}{l}30.6 \\
(1.5)\end{array}$ & $\begin{array}{l}54.4^{* *} \\
(3.9)\end{array}$ & $\begin{array}{l}41.5 \\
(16.0)\end{array}$ & $\begin{array}{l}104.7 * * \\
(26.2)\end{array}$ & $\begin{array}{l}4.8 \\
(0.0)\end{array}$ & $\begin{array}{l}7.5 * * \\
(0.1)\end{array}$ \\
\hline 2011 & $\begin{array}{l}145.8 \\
(18.3)\end{array}$ & $\begin{array}{l}249.5^{* * *} \\
(15.0)\end{array}$ & $\begin{array}{l}29.0 \\
(11.4)\end{array}$ & $\begin{array}{l}48.3 \\
(1.0)\end{array}$ & $\begin{array}{l}27.1 \\
(3.5)\end{array}$ & $\begin{array}{l}53.5^{* *} \\
(3.7)\end{array}$ & $\begin{array}{l}34.6 \\
(8.7)\end{array}$ & $\begin{array}{l}105.9 * * \\
(31.2)\end{array}$ & $\begin{array}{l}4.1 \\
(0.0)\end{array}$ & $\begin{array}{l}6.1 * * \\
(0.1)\end{array}$ \\
\hline 2012 & $\begin{array}{l}113.6 \\
(12.9)\end{array}$ & $\begin{array}{l}156.2 * \\
(10.3)\end{array}$ & $\begin{array}{l}39.2 \\
(25.1)\end{array}$ & $\begin{array}{l}47.1 \\
(19.6)\end{array}$ & $\begin{array}{l}21.4 \\
(2.6)\end{array}$ & $\begin{array}{l}33.7 * * \\
(2.4)\end{array}$ & $\begin{array}{l}98.7 \\
(22.2)\end{array}$ & $\begin{array}{l}117.9 \\
(39.1)\end{array}$ & $\begin{array}{l}5.2 \\
(0.0)\end{array}$ & $\begin{array}{l}9.0 * * \\
(0.1)\end{array}$ \\
\hline 2013 & $\begin{array}{l}131.0 \\
(14.4)\end{array}$ & $\begin{array}{l}166.0 * \\
(11.0)\end{array}$ & $\begin{array}{l}23.6 \\
(6.6)\end{array}$ & $\begin{array}{l}37.8 \\
(7.3)\end{array}$ & $\begin{array}{l}23.7 \\
(2.9)\end{array}$ & $\begin{array}{l}34.7 * * \\
(2.6)\end{array}$ & $\begin{array}{l}137.2 \\
(31.4)\end{array}$ & $\begin{array}{l}152.6 \\
(42.5)\end{array}$ & $\begin{array}{l}16.0 \\
(0.0)\end{array}$ & $\begin{array}{l}30.9 * * \\
(0.1)\end{array}$ \\
\hline
\end{tabular}

One asterisk and two asterisks indicate significant at $\mathrm{P}<0.05, \mathrm{P}<0.01$, respectively, between $\mathrm{R}$ and $\mathrm{F}$; values within parenthesis are standard deviations. 
Table A3. Mean nutrient concentration ( $\mathrm{mg} \mathrm{g}^{-1}$ dry weight) of macronutrients and boron in one-year-old foliage in the reference $(\mathrm{R})$ and fertilized $(\mathrm{F})$ stands, two years after the treatment commenced.

\begin{tabular}{lll}
\hline Nutrients & $\mathrm{R}$ & $\mathrm{F}$ \\
\hline $\mathrm{N}$ & $10.79(0.33)$ & $15.78(0.47)$ \\
$\mathrm{P}$ & $1.30(0.02)$ & $1.43(0.06)$ \\
$\mathrm{K}$ & $4.67(0.24)$ & $4.78(0.23)$ \\
$\mathrm{Ca}$ & $1.95(0.26)$ & $1.90(0.12)$ \\
$\mathrm{Mg}$ & $0.69(0.04)$ & $0.46(0.04)$ \\
$\mathrm{S}$ & $0.70(0.03)$ & $0.80(0.04)$ \\
$\mathrm{B}$ & $0.015(0.003)$ & $0.023(0.006)$ \\
\hline
\end{tabular}

